\title{
NESKELBIAMŲ DERYBŲ, KAIP IŠIMTINIO PIRKIMO BÜDO, PASIRINKIMO IR VYKDYMO YPATUMAI VIEŠŲJŲ PIRKIMŲ İTATYMO 56 STRAIPSNIO 1 DALIES 2 IR 4 PUNKTO PAGRINDU
}

\author{
Eglè Sakalauskaitè \\ Mykolo Romerio universiteto Teisès fakulteto \\ Konstitucinès ir administracinès teisès institutas \\ Ateities g. 20, LT-08303 Vilnius, Lietuva \\ Tel.: (+ 370) 52714545 \\ El. paštas: egles.sakalauskaites@gmail.com
}

Pateikta 2013 m. lapkričio 21 d., parengta spausdinti 2015 m. sausio 9 d.

doi:10.13165/SMS-14-6-3-15

Anotacija. Straipsnyje analizuojamos problemiškiausios neskelbiamu derybų, kaip pirkimo büdo, pasirinkimo sąlygos ir ju vykdymo ypatumai. Daugiausia demesio skiriama pagrindinems neskelbiamu derybu sąlygoms aptarti, pristatant aktualia teismu praktiką. Aptariami šie neskelbiamu derybu pasirinkimo atvejai: kai pirkimo büdas pasirenkamas dè ypatingos skubos ir nenumatytu ivykiu, taip pat dèl to, kad nebuvo gauta tinkamu pasiūlymų. Be to, siekiama išnagrinèti ex ante skelbimo tikslą. Straipsnyje taip pat nagrinejama neskelbiamu derybu samprata, aptariami atvejai, kai reikalingas Viešuju pirkimu tarnybos sutikimas atlikti pirkima neskelbiamu derybu büdu.

Straipsnyje pagrindinis demesys sutelktas ị praktikoje aktualiu problemu, pasirenkant neskelbiamy derybu büdą, nagrinèjima, siekiant išaiškinti atitinkamas teisès normas, reguliuojančias neskelbiamu derybü, kaip pirkimo büdo, pasirinkimą. Ketinama pateikti pasiūlymų, kaip sklandžiai ir tinkamai taikyti Lietuvos Respublikos viešujų pirkimu istatymo normas, reguliuojančias neskelbiamu derybų, kaip pirkimo būdo, pasirinkima ir jų vykdyma.

Socialinių mokslų studijos / Societal Studies

(C) Mykolo Romerio universitetas, 2014

(C) Mykolas Romeris University, 2014
ISSN 2029-2244 (online)

http://www.mruni.eu/lt/mokslo_darbai/SMS/ http://www.mruni.eu/en/mokslo_darbai/SMS/ 
Reikšminiai žodžiai: viešieji pirkimai, derybos, neskelbiamos derybos, pranešimas dèl savanoriško ex ante skaidrumo.

\section{Ivadas}

Pažymėtina, kad ne visais atvejais įmanoma atlikti viešuosius pirkimus atviro, riboto konkurso būdu dèl Lietuvos Respublikos viešųjų pirkimų įstatyme ${ }^{1}$ (toliau VPI) nustatytų terminų, susijusių su viešojo konkurso paskelbimu, tiek dẻl nemažai laiko reikalaujančių detaliai reglamentuotų procedūrų ar kitų priežasčių, dèl ko kyla grèsmè, kad nebus laiku įsigyta perkančiajai organizacijai reikalingų prekių, paslaugų ar darbų. Todèl VPIt reglamentuojami ir lankstesni pirkimo būdai, kaip skelbiamų bei neskelbiamų derybų sąlygos ir procedūros. Šiame straipsnyje pagrindinis dèmesys ir bus skiriamas būtent neskelbiamų derybų, kaip pirkimo būdo, pasirinkimo sąlygoms ir vykdymo ypatumams.

Atkreiptinas dèmesys ị tai, kad Lietuvoje 1999-2003 m. buvo galimi pirkimai iš vienintelio šaltinio, gavus Lietuvos Respublikos Vyriausybès sutikimą (Vyriausybès nutarimo projektas turèjo būti suderintas su Viešųjų pirkimų tarnyba (toliau - Tarnyba). Nuo $2003 \mathrm{~m}$. kovo $1 \mathrm{~d}$. ịsigaliojusiame VPI atsisakyta papildomų procedūrų, kuriomis buvo tikrinamas pirkimo iš vienintelio šaltinio būdas, jị VPI pakeitè neskelbiamos derybos. Pirkimas iš vienintelio šaltinio buvo mažiausiai skatinamas pirkimo būdas, nes, jị taikant, nėra konkurencijos, sunku užtikrinti pirkimo efektyvumą ir racionalų lěšu naudojimą, taip pat išvengti korupcijos. Taigi sukurtas mechanizmas stiprino kontrolę 2 .

Lietuvai siekiant tapti Europos Sąjungos nare, nacionaliniai teisès aktai turèjo būti suderinti su Europos Sąjungos teisès aktais. Nuo 2003 m. kovo 1 d. ịsigaliojusio VPI nuostatos buvo suderintos su Europos Sąungos teisès aktais ir pirkimas iš vienintelio šaltinio buvo pakeistas išsamiau reguliuojamu neskelbiamų derybų būdu.

Pažymètina, kad nuo 2012 m. sausio 1 d. įsigaliojo VPI nuostata, kuri numato, kad tarptautinès vertès pirkimas ${ }^{3}$ neskelbiamų derybų būdu gali būti pradedamas tik gavus Tarnybos sutikimą dèl minèto pirkimo būdo pasirinkimo. Toks įstatymo reikalavimas numatytas siekiant, kad perkančiosios organizacijos nepiktnaudžiautų šia išimtine VPI ịstatymo numatyta teise pasirinkti neskelbiamų derybų būdą, kartu siekiant mažinti galimų korupcijos atvejų tikimybę. Pažymėtina, kad kartu su minèta

1 Lietuvos Respublikos viešųjų pirkimų įstatymas. Valstybés žinios. 1996, Nr. 84-2000; 2006, Nr. 4-102.

2 Ambrazevičienè, R. Teisètumo užtikrinimo priemonès vykdant viešuosius pirkimus. Jurisprudencija. 2003, 46(38).

3 Pastaba. Kai numatoma pirkimo vertè viršija tarptautinio pirkimo vertės ribą (vertės ribas žr. $<$ http://www.vpt.lt/vpt/uploaded/Vertes\%20ribos\%202012.pdf >). Supaprastintų pirkimų vykdymas reglamentuojamas VPĮ IV skyriuje ir šie pirkimai atliekami pagal perkančiųjų organizacijų patvirtintas taisykles, Pavyzdžiui, VPI 92 straipsnyje numatyti atvejai, kai neskelbiant apie pirkimą gali būti perkamos prekès ir paslaugos. 
teisès norma atsiranda galimybė skųsti Tarnybos priimtus sprendimus, jei Tarnyba nesutinka, kad perkančioji organizacija konkrečiu atveju pasirinktų neskelbiamų derybų būdą.

Nauji VPI pakeitimai dèl Tarnybos sutikimo gavimo sukèlè daug diskusijų. 2013 m. rengiant VPI pakeitimus buvo diskutuota, ar tikrai visada reikalingas Tarnybos sutikimas dèl neskelbiamų derybų pasirinkimo, ar jis reikalingas tik didelès vertès pirkimų atveju, ar sutikimo gavimas tèra papildoma administracinè našta, ar Tarnybos sutikimų išdavimo praktika iš tikrųjų prisideda prie korupcijos rizikos mažinimo perkant prekes, paslaugas ar darbus neskelbiamų derybų būdu. Ūkio ministerija, rengdama VPI pakeitimus, argumentavo, kad už viešųjų pirkimų vykdymą yra atsakinga pati perkančioji organizacija ${ }^{4}$. Tačiau, pavyzdžiui, Transparency International Lietuvos skyrius (toliau - TILS) ${ }^{5}$ nepritare įstatymo projekte siūlomai nuostatai, kuri

Žr. Lietuvos Respublikos viešųjų pirkimų ịstatymo $2,4,6,7,8^{2}, 9,10,13,18,22,24,28,33$, $35,39,40,56,85,86,87,90$ ir 92 straipsnių pakeitimo ir papildymo ịstatymo projekto aiškinamasis raštas [interaktyvus]. [žiūrèta 2013-09-01]. <http://www3.lrs.lt/pls/inter3/dokpaieska. showdoc_l?p_id=447967\&p_tr2=2> Aiškinamajame rašte teigiama, kad Lietuvos Respublikos Vyriausybė remia siekị kovoti su ydinga išimtinių neskelbiamų derybų ir vidaus sandorių taikymo praktika, kuri apriboja konkurenciją, mažina skaidrumą, kelia neracionalaus lešų panaudojimo ir korupcijos riziką. Tačiau pažymètina, kad už viešųjų pirkimų vykdymą yra atsakinga pati perkančioji organizacija. Europos Teisingumo Teismas yra pripažinęs, kad viešųjų pirkimų taisyklių išimtys turi būti aiškinamos griežtai, o išimtinių aplinkybių, pateisinančių nukrypimą nuo šių taisyklių, buvimą turi ịrodyti asmuo, siekiantis jomis pasinaudoti (1995 m. gegužès 18 d. Sprendimo Komisija prieš Italiją, C-57/94, 23 punktas; 2004 m. rugsejo 14 d. Sprendimo Komisija prieš Italiją, C-385/02, 19 punktas). İstatymas perkančiajai organizacijai nustato griežtas sankcijas už neteisètą išimtinių neskelbiamų derybų ar vidaus sandorių vykdymą - taip sudarytą pirkimo sutartį teismas turi pripažinti negaliojančia. Taip pat atkreiptinas dèmesys, kad sutikimų gavimas iš VPT padidina administracinę naštą perkančiosioms organizacijoms, be to, sutikimų išdavimas ilgai užtrunka (İstatymas numato nuo 20 iki 40 darbo dienų), todèl perkančioji organizacija negali pradèti ar nutraukti pirkimo. VPT pateiktoje informacijoje apie $2012 \mathrm{~m}$. ịvykusius viešuosius pirkimus nurodè, kad davè sutikimą atlikti pirkimą neskelbiamų derybų būdu - 153 atvejais, nedavè - 23; davè sutikimą atlikti vidaus sandorị - 72, nedavé 7; davé sutikimą nutraukti pirkimo procedūras - 68 (supap. p.) ir 41 (tarpt. p.), nedavé - 46 (supap.p.) ir 19 (tarpt.p.). Svarbu atkreipti demesị i situaciją, kai perkančioji organizacija pirkimą atlieka neskelbiamų derybų būdu, ypač kai kreipiasi ị vienintelị tiekejją. Tokiu atveju neracionalu reikalauti VPT sutikimo norint nutraukti procedūras, kai pati perkančioji organizacija kviečia tiekejus derètis ir geriausiai gali ịvertinti situaciją. Atsižvelgiant ị tai Įstatymo projekto 4 straipsnio 3 dalyje siūloma atsisakyti VPT sutikimų gavimo norint nutraukti neskelbiamų derybų būdu atliekamų pirkimų ir supaprastintų pirkimų procedūras. Taip pat İstatymo projekto 5 straipsnyje, 7 straipsnio 4 dalyje ir 17 straipsnyje, siekiant išvengti kylančių grèsmių dèl neskelbiamų derybų ir vidaus sandorių vykdymo, siūloma nustatyti, kad VPT sutikimas reikalingas tik atliekant didelès apimties pirkimą neskelbiamų derybų būdu ar sudarant didelès apimties vidaus sandorị.

5 Žr. Tranparency International Lietuvos skyriaus pastabos dẻl siūlomų Viešųjų pirkimų ịstatymo pataisų [interaktyvus]. [žiūrèta 2013-09-01]. <http://transparency.lt/media/filer_public/2013/05/14/tils_lrs_del_viesuju_pirkimu_istatymo_pakeitimo.p >. TILS nuomone, tai prisidètų prie korupcinių rizikų didinimo tokiuose sandoriuose. Tiek užsienio šalių praktikoje, tiek Europos Sąjungos Teisingumo Teismo praktikoje pripažistama, jog neskelbiamos dery- 
leistų pirkimus, išskyrus didelès apimties pirkimus, neskelbiamų derybų būdu vykdyti be Tarnybos leidimo, motyvuodmas šio pirkimo būdo rizikingumu. Galutiniame rezultate Lietuvos Respublikos Seime svarstant VPI pakeitimus, išliko nuostata, kad Tarnybos sutikimas reikalingas, norint vykdyti pirkimą neskelbiamų derybų būdu (išskyrus tam tikras išimtis).

Lietuvos Respublikos valstybès kontrolès ${ }^{6}$ ataskaitoje teigiama, kad Tarnyba daugeliu atveju nustačiusi, jog perkančiosios organizacijos, naudodamos neskelbiamų derybų pirkimo būdą, piktnaudžiauja. Pirkdamos tokiu būdu, derybų kviečia vieną tiekèją arba nurodo nenumatytas aplinkybes ir perka skubos tvarka. Europos Komisijos metinejje viešujų pirkimų igyvendinimo apžvalgoje ${ }^{7}(2013 \mathrm{~m}$.) taip pat pažymima, kad derybų procedūra yra vis dar viena iš procedūrų, kuri yra labiausiai veikiama taikymo klaidų.

Taigi, pirkimo neskelbiamų derybų būdu pasirinkimas turètų būti ne dažna praktika, o daugeliu atvejų išimtis, vykdant pirkimus naudojant tiek Lietuvos valstybès biudžeto, tiek ir Europos Sąjungos fondų lèšas.

Šio straipsnio objektas - neskelbiamų derybų, kaip pirkimo būdo, pasirinkimo sąlygos ir vykdymo ypatumai VPI 56 straipsnio 1 dalies 2 ir 4 punkto pagrindu. Straipsnio tikslas yra išnagrinèti derybų sampratą, analizuoti problemiškiausius neskelbiamų derybų, kaip išimtinio pirkimo būdo, pasirinkimo atvejus, aptarti Tarnybos sutikimų vykdyti pirkimą neskelbiamų derybų būdu išdavimo atvejus. Tikslui pasiekti iškeliamas uždavinys: padèti perkančiosioms organizacijoms sklandžiau bei tinkamai taikyti VPĮ normas pasirenkant neskelbiamų derybų būdą bei vykdant pirkimą tokiu pirkimo būdu.

Straipsnyje taip pat analizuojami ex ante skelbimo tikslai - tai, kaip siekiama užtikrinti savanorišką išankstinị skaidrumą.

Straipsnyje remiamasi prancūzų ir anglų autorių atliktais moksliniais tyrimais, kuriuose nagrinėjamos neskelbiamų derybų, kaip pirkimo būdo, pasirinkimo sąlygos ir ypatumai.

Taikomi gramatinis, sisteminis, loginis, lyginamasis, dokumentų analizės ir kiti metodai.

\section{Neskelbiamų derybų samprata}

VPI 42 straipsnio 1 dalyje ịtvirtinti šie prekių, paslaugų ar darbų pirkimo būdai: 1) atviras konkursas; 2) ribotas konkursas; 3 ) konkurencinis dialogas; 4) skelbiamos ir neskelbiamos derybos. To paties straipsnio 2 dalyje numatyta, kad perkančioji

bos - korupcijos atžvilgiu vienas rizikingiausių viešųjų pirkimų būdų. Turint omenyje, kokia dalis pirkimų Lietuvoje atliekama neskelbiamų derybų būdu (2012 m. bendra tokių pirkimų vertè buvo $267,8 \mathrm{mln}$. LTL).

6 Lietuvos Respublikos valstybès kontrolès išankstinio tyrimo ataskaita. Viešųjų pirkimų sistemos apžvalga, $2011 \mathrm{~m}$. lapkričio 25 d. IT-P-20-1-14, p. 36.

7 [interaktyvus]. [žiūrèta 2014-12-20]. <ec.europa.eu/.../20140820-staff-working-document_en>. 
organizacija pirkimą gali atlikti: 1) atviro ar riboto konkurso būdu (visais atvejais); 2) konkurencinio dialogo būdu (esant VPI 50 straipsnyje nustatytoms sąlygoms); 3) skelbiamų derybų būdu (esant VPI 55 straipsnyje nustatytoms sąlygoms); 4) neskelbiamų derybų būdu (esant VPI 56 straipsnyje nustatytoms sąlygoms). Atvirame, ribotame konkurse derybos tarp perkančiosios organizacijos ir tiekejjų draudžiamos.

Dabartiniame lietuvių kalbos žodyne ${ }^{8}$ nurodytos šios pagrindinès termino derybos reikšmès: 1 . tarimasis sudaryti sutartị; 2. lygimas, derejjimasis, ką perkant ar parduodant.

VPI 2 straipsnis ịtvirtina, kad derybos - pirkimo būdas, kai perkančioji organizacija konsultuojasi su pasirinktais tiekejjais ir su vienu ar keliais iš jų derasi dèl pirkimo sutarties sąlygu. Taigi, derybų atveju su pasirinktais tiekejjais tariamasi (deramasi) dèl geriausių pirkimo sutarties sąlygų, siekiant tiek perkančiajai organizacijai, tiek ir tiekejui priimtiniausio rezultato.

Nepriklausomai nuo derybų pobūdžio, visoms joms būdingi tam tikri požymiai: derybose dalyvauja mažiausiai dvi šalys; egzistuoja nesuderinamumas tarp šalių pozicijų (t. y. tai, ko nori viena šalis, nesutampa su tuo, ko siekia kita šalis); derybos yra savanoriškas procesas (t. y. derybos vyksta tada, kai šalys pačios nori pasiekti susitarimą); derèdamosi šalys tikisi „duoti ir gauti“ (t. y. kiekviena šalis yra pasirengusi keisti savo pradinị siūlymą ar reikalavimą) ${ }^{9}$. Taigi visais atvejais, ar tai būtų verslo derybos, ar derybos pagal VPI, derantis siekiama geriausio rezultato, priimtino abiem pusèms, lyginant su pradiniu siūlymu.

VPI numatytos dvi derybų rūšys: skelbiamos (viešasis pirkimas, kuris vykdomas apie ji paskelbiant viešai) ir neskelbiamos (kai apie pirkimą neskelbiama viešai). Perkančioji organizacija, atsižvelgama i VPI nustatytas sąlygas, gali pasirinkti, ar pirkimą vykdyti skelbiamų (VPI 55 straipsnis), ar neskelbiamų derybų būdu (VPI 56 straipsnis). VPI 57 straipsnis reglamentuoja tiek skelbiamų, tiek ir neskelbiamų derybų vykdymą ${ }^{10}$, VPI 58 straipsnis numato tiek neskelbiamų, tiek skelbiamų derybų reikalavimus ${ }^{11}$.

8 Dabartinès lietuviu kalbos žodynas. Vyr. red. S. Keinys. Vilnius: Mokslo ir enciklopedijų leidybos institutas, 2012, p. 116.

9 Diržyte, A.; Sondaitė, J.; Norvilè, N. Verslo psichologija. Vilnius: Mykolo Romerio universitetas, 2012, p. 52-53.

10 Atkreiptinas dèmesys, kad klasikinio sektoriaus organizacijos (VPI 4 straipsnio 1 dalies 1, 2 ar 3 punkte nurodytos perkančiosios organizacijos), noredamos atlikti viešąji pirkimą neskelbiamų derybų būdu, privalo vadovautis VPI 56 straipsniu, o komunalinio sektoriaus organizacijos (VPI 4 straipsnio 1 dalies 4 punkte nurodytos perkančiosios organizacijos, t. y. organizacijos, veikiančios vandentvarkos, energetikos, transporto ar pašto paslaugų srityje) atitinkamai vadovaujasi VPI 73 straipsniu. Minètuose straipsniuose numatytos pirkimo neskelbiamų derybų būdu sąlygos, kai prekès, paslaugos ar darbai gali būti perkami neskelbiamų derybų būdu.

11 Derybų procedūrų metu perkančioji organizacija turi laikytis šių sąlygų: 1) derybas su kiekvienu tiekèju vesti atskirai; 2) tretiesiems asmenims neatskleisti jokios iš tiekejo gautos informacijos be šio sutikimo, taip pat neinformuoti tiekejo apie susitarimus, pasiektus su kitais tiekejjais; 3) visiems dalyviams turi būti taikomi vienodi reikalavimai, suteikiamos vienodos 
Teisingai teigia Sue Arrowsmith, jog skelbiamos derybos yra artimesnès atviram ar ribotam konkursui nei neskelbiamos ${ }^{12}$, kadangi neskelbiamu derybu atveju perkančioji organizacija, viešai neskelbdama konkurso, pasirenka tiekejją. Neskelbiamų derybų atveju perkančioji organizacija kreipiasi i tiekẻją (tiekejjus), prašydama pateikti pasiūlymą (pasiūlymus), ir vykdo derybas VPİ nustatyta tvarka. Labai svarbu užtikrinti skaidrumą tiek pasirenkant pati pirkimo būdą, tiek ir pradejjus jau pačias pirkimo procedūras, t. y. ir pasirenkant tiekejjus, su kuriais bus vykdoma derybu procedūra, ir vykdant pačias derybas, siekiant, kad būtų užtikrinta sąžininga dalyvių konkrencija. Skatintina, kiek leidžia galimybès, kviesti kuo daugiau tiekejjų, galinčių pateikti pasiūlymą, atitinkantị perkančiosios organizacijos poreikius. Perkančioji organizacija turi pagrịsti savo sprendimus: tiek dèl pačio pirkimo būdo pasirinkimo, tiek dèl tiekejjų pasirinkimo ir pan. LAT, pavyzdžiui, laiko teisiškai nereikšmingais argumentus, kad vieno tiekèjo pakvietimas ị neskelbiamas derybas pateisinamas siekiu išvengti sunkumų, nustatant skirtingų rangovų, stačiusių tą patị objektą, atsakomybę $e^{13}$.

Kyla klausimas, kaip turètų elgtis perkančioji organizacija, pavyzdžiui, jeigu nekviestas tiekejjas išreiškia pageidavimą dalyvauti pirkime? Perkančiajai organizacijai néra numatyta prievolè tokị tiekejją pakviesti, tačiau, jei yra galimybè ir ịstatyme nèra numatytų tam tikrų apribojimų, tikslinga potencialų tiekejją pakviesti ir sudaryti sąlygas sąžiningai tiekejjų konkurencijai. VPI numatyti atvejai, kai neskelbiamų derybų atveju kviečiami visi pasiūlymus pateikę tiekẻjai, t. y. kai atliekant pirkimą, apie kurị buvo skelbta, visi gauti pasiūlymai neatitiko pirkimo dokumentų reikalavimų arba buvo pasiūlytos per didelès perkančiajai organizacijai nepriimtinos kainos, o pirkimo sąlygos iš esmès nekeičiamos ir ị neskelbiamą pirkimą kviečiami visi pasiūlymus pateikę tiekèjai, atitinkantys perkančiosios organizacijos nustatytus minimalius kvalifikacijos reikalavimus.

Perkančioji organizacija skelbiamas derybas vykdo šiais etapais: pirmiausia derybas skelbia viešai, VPİ 22 („Viešųjų pirkimų skelbimai“) ir 23 („Skelbimų rengimas ir skelbimas") straipsniuose nustatyta tvarka kviečia tiekèjus teikti paraiškas dalyvauti

galimybès ir pateikiama vienoda informacija; teikdama informaciją perkančioji organizacija neturi diskriminuoti vienų tiekèjų kitų naudai; 4) derybos turi būti protokoluojamos. Derybų protokolą pasirašo Komisijos pirmininkas ir dalyvio, su kuriuo derètasi, igaliotas atstovas; 5) pasiūlymai, kuriuose nurodytos galutinès tiekèjų siūlomos kainos, taip pat galutiniai techniniai duomenys, kurie vertinami pagal ekonomiškai naudingiausio pasiūlymo vertinimo kriterijus, turi būti pateikiami užklijuotuose vokuose. Ši nuostata gali būti netaikoma šio ístatymo 56 straipsnio 1 dalies 4 punkte, 73 straipsnio 1 dalies 4 punkte nustatytais ar kitais atvejais, kai pasiūlymą pateikia vienas tiekejas. 2. Perkančioji organizacija atskirai derasi su kiekvienu dalyviu, atitinkančiu perkančiosios organizacijos nustatytus kvalifikacijos reikalavimus, ir nustato geriausią pasiūlymą pagal šio įstatymo 39 straipsnio nuostatas.

12 Arrowsmith, S. The law of Public and Utilities procurement. London: Sweet and Maxwell, 2005.

13 Lietuvos Aukščiausiojo Teismo Civilinių bylų skyriaus teisejų kolegijos $2009 \mathrm{~m}$. lapkričio $13 \mathrm{~d}$. nutartis civilineje byloje Vilniaus miesto apylinkès vyriausiasis prokuroras prieš Vilniaus miesto savivaldybę ir kt. (bylos Nr. 3K-3-505/2009). 
skelbiamose derybose. Atkreiptinas dèmesys, kad pačios derybos turi būti vykdomos griežtai laikantis VPĮ nustatytos tvarkos ir pagrindinių viešųjų pirkimų principų.

Remiantis VPI , neskelbiamos derybos yra viešasis pirkimas, tačiau vykdant pirkimą viešumo iš esmès nelieka, išskyrus galimą kontrolę, išankstinị ex ante pranešimą. Keltinas klausimas, ar neskelbiamos derybos yra viešasis pirkimas, ar tik tiesioginis sutarties sudarymas, nes dažniausiai dèl tam tikrų aplinkybių pasirenkamas deryboms tik vienas tiekejas, su kuriuo sudaroma sutartis - tik kai kuriais atvejais vykdomos derybos su keletu tiekeju.

Taigi, teiginys „pirkimą vykdyti neskelbiamų derybų būdu“ pirmiausia reiškia specialų pirkimo būdą, kurị galima pasirinkti perkant prekes, paslaugas ar darbus, tik esant tam tikroms ịstatyme numatytoms ypatingoms sąlygoms. Vykdant pirkimą leidžiama derètis su vienu ar keliais tiekejjais dèl pirkimo sutarties sąlygų.

Pažymètina, kad VPĮ 3 straipsnis numato pagrindinius viešųjų pirkimų principus, kurių privaloma laikytis atliekant pirkimo procedūras. Perkančioji organizacija turi užtikrinti, kad, atliekant pirkimo procedūras ir nustatant laimètoją, būtų laikomasi lygiateisiškumo, nediskriminavimo, abipusio pripažinimo, proporcingumo ir skaidrumo principų. Atlikti pirkimą neskelbiamų derybų būdu galima tik griežtai laikantis VPİ numatytų sąlygų bei principų, siekiant racionaliai panaudoti pirkimui skirtas lèšas, skatinant konkurenciją, o ne tik užtikrinant formalias procedūras. Perkančiosios organizacijos turi užtikrinti lygiateisiškumą visų dalyvių atžvilgiu vesdama derybas, negali numatyti informacijos, kuri diskriminuotų dalyvius, siekiant užtikrinti sąžiningą konkurenciją.

ETT praktikoje pažymima, kad pagrindinis Bendrijos normų dèl viešųjų pirkimų tikslas yra užtikrinti neiškraipytą konkurenciją visose valstybėse narèse ${ }^{14}$. Nors VPI ịtvirtintas pirkimų tikslas siejamas su ịsigijimu reikalingų prekių, paslaugų ar darbų racionaliniai naudojant tam skirtas lèšas, tačiau LAT ${ }^{15}$ yra pasisakęs, kad nesuvaržyta tiekejų konkurencija - iš VPI implicitiškai išplaukiantis reikalavimas, jo neittvirtinimas ịstatyme expressis verbis nepaneigia šio perkančiajai organizacijai keliamo reikalavimo, nes pagrindinis viešųjų pirkimų procedūrų reglamentavimo siekis - užtikrinti konkurenciją. Neskelbiamų derybų pirkimo išskirtinumą lemia tai, kad jų metu nèra užtikrinama pakankama tiekejjų konkurencija, kaip kad vykdant iprastines atviras pirkimo procedūras, o deramasi tik su vienu ar keliais pasirinktais tiekejais. Taigi, tam tikra prasme tiekejų teisès suvaržomos. Norint pasirinkti pirkimo neskelbiamomis derybomis būdą, turi būti objektyvios VPĮ ir direktyvose ${ }^{16}$ numaty-

14 Byla C-450/06, Varec SA v. Belgium, Diehl Remschied GmbH \& Co. 2008.

15 Lietuvos Aukščiausiojo Teismo Civilinių bylų skyriaus teisejų kolegijos $2011 \mathrm{~m}$. gegužès $24 \mathrm{~d}$. nutartis civilineje byloje $A B$ „Specialus autotransportas“ prieš Klaipédos miesto savivaldybès administracija (bylos Nr. 3K-3-249/2011).

16 Derybų procedūra ir jos vykdymas taip pat reglamentuojama Europos Sąungos direktyvose: 2004 m. kovo 31 d. Europos Parlamento ir Tarybos direktyvos 2004/18/EB „Dél viešojo darbų, prekių ir paslaugų pirkimo sutarčių sudarymo tvarkos derinimo“" (toliau - Klasikinio sektoriaus direktyva) ir $2004 \mathrm{~m}$. kovo 31 d. Europos Parlamento ir Tarybos direktyvos 2004/17/EB 
tos sąlygos. Europos Sąjungos Teisingumo Teismas (toliau - ETT) vienoje iš bylų atkreipè dèmesị i tai, kad tiekejjų teisių suvaržymas galimas tik tuo atveju, kai egzistuoja išimtinés aplinkybès ${ }^{17}$. Aplinkybių pasirinkimo įrodinejjimo našta tenka tai šaliai, kuri tomis aplinkybèmis rèmèsi ${ }^{18}$.

ETT pažymėjo, kad neskelbiamų derybų procedūra yra išimtinè, todèl turi būti taikoma griežtai tik tais atvejais, kurie numatyti baigtiniame jos taikymo pagrindų sąraše ${ }^{19}$.

Prancūzų autoriai (C. Ribot, E. Marcas, P. Odoux) nurodo, kad visais atvejais teismas atidžiai ịvertina derybų procedūros būtinumą, kad tai nebūtų pretekstas, leidžiantis perkančiajai organizacijai išvengti ịsipareigojimų vykdyti ịprastines viešas konkurso procedūras ${ }^{20}$.

Nors neskelbiamų derybų, kaip pirkimo būdo, taikymas praktikoje dažnai gana sudètingas, tačiau vykdant derybas yra kartu galimybė derantis efektyviau i̇sigyti prekių, paslaugų ar darbų, jei tik tinkamai laikomasi įstatyme numatytų taisyklių, užtikrinama sąžininga dalyvių konkurencija, procedūrų skaidrumas, nèra proteguojamos vienos ar kitos įmonès. Taigi, svarbu ne tik kad formaliai teisingai būtų atliktos pirkimo procedūros, tačiau ir ịgyvendinti viešųjų pirkimų principai bei pasiekti viešųjų pirkimų tikslai.

Atkreiptinas dėmesys ị tai, kad tiekèjai, kurie mano, kad jų teisės pažeistos, turi teisę ginti savo teises VPI nustatyta tvarka ${ }^{21}$.

„Dèl subjektų, vykdančių veiklą vandens, energetikos, transporto ir pašto paslaugų sektoriuose, vykdomų pirkimų tvarkos derinimo" (toliau - Komunalinio sektoriaus direktyva).

Byla C-57/94, Commission of European Community v. Italy [1995] ECR I-1949.

18 Ibid.

19 Byla 84/03, Commission of European Communities v. Kingdom of Spain [1984].

20 Ribot, C.; Marc, E.; Idoux, P. Dico Moniteur des marchés publics: définitions, textes officiels, jurisprudences et avis, Le Moniteur Editions, 2008. Autoriai kaip pavyzdị aptaria atveji, susijusi su sporto komplekso atnaujinimu. Autorių teigimu, tai, kad pirkimo sąlygose numatyta, jog rangovo projektavimo darbų rezultatai negalès būti naudojami kitaip, kaip kad tik numatyto pirkimo poreikiams, nesudaro pakankamo pagrindo daryti išvadą, jog su ta pačia ịmone pirkimą galima būtų vykdyti neskelbiamų derybų būdu. Taip pat nurodo, kad neskelbiamų derybų procedūra neleidžia perkančiajai organizacijai modifikuoti esminių pirkimo sąlygų, tokių kaip pirkimo objekto ar kandidatų atrankos kriterijų ir pasiūlymo. Galima derètis dèl kainos, kokybės, kiekio, terminų, sutarties ịvykdymo garantijų ir pan. (baudų, sutarties nutraukimo). Minèti autoriai nurodo, kad vis dèlto derybų atveju perkančioji organizacija turi užtikrinti kandidatų lygiateisiškumą ir skaidrumą visos procedūros metu, taip pat turi būti užtikrinta tiekèjų gamybinè ar komercinè paslaptis. $<\ldots>$

21 Pažymėtina, kad tiekejas, kuris mano, kad perkančioji organizacija nesilaikẻ šio ịstatymo reikalavimų ir tuo pažeide (ar ketina pažeisti) teisètus jo interesus (kartu ir dèl neskelbiamų derybu būdo pasirinkimo ar vykdymo procedūru teisètumo), VPI nustatyta tvarka gali kreiptis i̇ apygardos teismą, kaip pirmosios instancijos teismą, dèl perkančiosios organizacijos sprendimų, neatitinkančių šio įstatymo reikalavimų, panaikinimo ar pakeitimo, dèl žalos atlyginimo, dèl pirkimo sutarties pripažinimo negaliojančia, dèl alternatyvių sankcijų taikymo. Atkreiptinas dėmesys ị tai, kad tuo atveju, jei Europos Komisija ịtartų neteisètą neskelbiamų derybų būdo pasirinkimą, ji galètų pradèti Europos teisès pažeidimo tyrimo procedūrą. 


\section{Tarnybos sutikimų išdavimas vykdyti pirkimą neskelbiamų derybų būdu}

VPI numato, kad Tarnybos sutikimas reikalingas, norint vykdyti pirkimą neskelbiamų derybų būdu. Kartu VPI numato ir atvejus, kai Tarnybos sutikimas nereikalingas, jeigu perkančioji organizacija ketina paskelbti pranešimą dèl savanoriško ex ante skaidrumo ir informaciją apie tai nurodo pirkimo dokumentuose arba jeigu pirkimas atliekamas pagal VPI 56 straipsnio 1 dalies 4 punktą (t. y. dèl nenumatyto ịvykio ir ypatingos skubos). Atkreiptinas dèmesys ị tai, kad Taisyklių 39 punkte numatyta, jog, atliekant pirkimą pagal VPI 56 straipsnio 1 dalies 4 punktą, Tarnybos sutikimas nereikalingas, tačiau šiuo atveju perkančioji organizacija, prièmusi sprendimą dèl pirkimo büdo pasirinkimo, nedelsdama, bet ne vèliau kaip per 5 darbo dienas Tarnybai teikia pagrindimą ${ }^{22}$.

Apie Tarnybos atliekamas funkcijas dar 2004 m. pareiškè „Sigma“ ekspertai, teigdami, kad, „vienai įstaigai atliekant daug skirtingų funkcijų, gali kilti interesų konfliktas. Pagal Europos Sąjungos direktyvas ir Europos Teisingumo Teismo sprendimus perkančiosios organizacijos, atliekančios pirkimus, yra atsakingos už savo veiksmų teisètumą. Nuspręsti, ar viešieji pirkimai vykdomi pagal VPİ, yra teismų kompetencija. Atkreipiamas dėmesys ị tai, kad Tarnybos funkcijų spektras platus, per gana trumpą laiką reikia priimti daug sprendimų, sunkiai ịmanoma atlikti išsamius tyrimus tam tikrais sudètingais atvejais, todèl atsiranda galimybe suklysti duodant sutikimą. Toks klaidingo sutikimo davimas gali lemti, kad perkančioji organizacija turès padengti tiekejjui dèl šios priežasties atsiradusius nuostolius, arba bus nustatyta atsakomybè Tarnybai“"23. Be to, Valstybès kontrolès ataskaitoje konkrečiai keliamas klausimas, kokią atsakomybę turètų prisiimti Tarnyba, jeigu teismas pripažintų ne-

22 Perkančioji organizacija pateikdama pagrindimą turi nurodyti: a) pirkimo pavadinimą, jei pirkimas finansuojamas Europos Sąjungos fondų lèšomis, projektą igyvendinančiąją instituciją bei projekto pavadinimą; b) pirkimo vertę ir informaciją apie pirkimui skirtas lěšas (suma bei finansavimo šaltinis), tai pagrindžiančius dokumentus; c) nuo perkančiosios organizacijos nepriklausančias aplinkybes, kurioms susidarius perkančioji organizacija taike išimtị pasirenkant pirkimo būdą, ir motyvus, pagrindžiančius, kad pirkimas negali būti atliktas kitais pirkimo būdais. Perkančioji organizacija pateikia tokias aplinkybes patvirtinančių dokumentų kopijas bei perkančiosios organizacijos Komisijos posèdžio motyvuoto protokolo kopiją, kuriuo priimtas sprendimas pasirinkti neskelbiamų derybų būdą vadovaujantis İstatymo 56 straipsnio 1 dalies 4 punktu.

23 VPT informacinis biuletenis 2004 m. sausis Nr. 1 (10) Viešujų pirkimu sistema Lietuvoje „Sigma akimis" Andrius Meiženis, Metodologijos ir mokymo skyriaus vyriausiasis specialistas. Pastaba. Europos Parlamento ir Tarybos 2007 m. gruodžio 11 d. direktyva 2007/66/EB, iš dalies keičiančios Tarybos direktyvas 89/665/EEB ir 92/13/EEB dèl viešųjų sutarčių suteikimo peržiūros procedūrų veiksmingumo didinimo (toliau - Direktyva Nr. 2007/66, direktyva 89/665/EEB) (Peržiūros direktyvos) numato, kad peržiūros institucija pirmąja instancija gali būti ir ne teisminè. 
galiojančia sutartị, kuri sudaryta neteisètai atlikus neskelbiamas derybas, gavus Tarnybos sutikimąa ${ }^{24}$.

TILS atlikta analizè atskleidé, kad 2006-2010 m. ministerijų vykdytų neskelbiamų viešųjų pirkimų suma nuo 2006 iki $2008 \mathrm{~m}$. padidèjo 52 proc., tačiau nuo $2008 \mathrm{~m}$. iki $2010 \mathrm{~m}$. ji sumažejo 79 proc. Iš viso per lyginamąji laikotarpị (2006-2010 m.) šio tipo viešųjų pirkimų suma sumažejo 60 proc. Taip pat minètoje analizėje nurodoma, kad per 2006-2010 m. visų LR ministerijų neskelbiamų viešųų pirkimų sutartys sudaré $29,5 \%$ visų viešųjų pirkimų sutarčų vertès ${ }^{25} .2012 \mathrm{~m}$. ̣̂sigaliojusiais VPI pakeitimais siekta sumažinti šio išimtinio būdo taikymą, tačiau TILS atlikta analizè rodo, kad ir anksčiau pirkimų apimtys mažejo, pavyzdžiui, kaip minèta ministerijų vykdytų neskelbiamų viešųjų pirkimų suma nuo 2008 iki 2010 m. sumažèjo 79 proc. Svarstytina, ar visais ịstatyme numatytais atvejais dèl neskelbiamų derybų vykdymo tikslingas Tarnybos sutikimas. Perkančioji organizacija visais atvejais atsakinga už viešujų pirkimų vykdymą įstatymų nustatyta tvarka (už viešųjų pirkimų komisijos veiksmus atsako ją sudariusi organizacija).

Pavyzdžiui, remiantis Centrinès viešųjų pirkimų informacinès sistemos duomenimis, laikotarpiu 2012-08-30-2013-10-08 Tarnyba gavo 200 prašymų dèl sutikimų pirkimą vykdyti neskelbiamų derybų būdu, iš jų išduota: 171 sutikimas ir 29 atvejais Tarnyba neleido pirkimą vykdyti neskelbiamų derybų būdu.

Kartu atkreiptinas demesys ir ị tai, kad, Tarnybos duomenimis, pirmąji $2012 \mathrm{~m}$. pusmetị, palyginti su $2011 \mathrm{~m}$. tuo pačiu laikotarpiu, neskelbiamų pirkimų skaičius sumažejo 23 proc. Neskelbiami pirkimai sudare 19,8 proc. visų per $2012 \mathrm{~m}$. pusmetị vykdytų viešųjų pirkimų skaičiaus. Tai beveik 5 proc. mažiau nei 2011 m., kai minèti pirkimai sudare beveik ketvirtị (24,7 proc.) visų per $2011 \mathrm{~m}$. pirmąji pusmetị vykdytų viešųjų pirkimų ${ }^{26}$. Tokia tendencija galima dèl to, kad nuo $2012 \mathrm{~m}$. sausio 1 d. ịsigaliojo VPI ịstatymo nuostata, numatanti, kad pirkimas neskelbiamų derybų būdu (išskyrus tam tikras ịstatyme numatytas išimtis) gali būti pradedamas tik gavus Tarnybos sutikimąa ${ }^{27}$.

Taigi, pirkimų skaičius neskelbiamų derybų būdu sumažèjo, tačiau pastebėtina ir tai, kad Tarnyba per pirmąji 2012 m. pusmetị davé dvigubai daugiau VPI numatytų

24 Lietuvos Respublikos valstybès kontrolès išankstinio tyrimo ataskaita. Viešųjų pirkimų sistemos apžvalga, $2011 \mathrm{~m}$. lapkričio $25 \mathrm{~d}$. IT-P-20-1-14.

25 „Transparency International“ Lietuvos skyrius (TILS). Lietuvos Respublikos ministerijų 20062010 metais vykdytų neskelbiamų viešųjų pirkimų analizė [interaktyvus]. [žiūrèta 2013-09-01]. $<$ http://transparency.lt/media/filer_public/2013/01/22/lr_ministeriju_20062010_metais_vykdytu_neskelbiamu_viesuju_pirkimu_analize.pdf $>$.

26 Viešųjų pirkimų tarnyba. Viešuju pirkimu tendencijos gerèja [interaktyvus]. [žiūrèta 2013-0901]. <http://www.vpt.lt/rtmp8/dtd/index.php?nid=1221469456\&module=news\&lan=LT>.

27 Prašymai pateikiami Perkančiųjų organizacijų prašymų dẻl Viešųjų pirkimų tarnybos sutikimų pateikimo ir nagrinèjimo ir pagrindimų Viešųjų pirkimų ịstatymo 56 straipsnio 5 dalyje nustatytais atvejais teikimo Viešųjų pirkimų tarnybai taisyklių, patvirtintų VPT direktoriaus 2014 m. spalio 6 d. ịsakymu Nr. 1S-164 (Teisès aktu registras. 2014, Nr. 2014-13796) nustatyta tvarka. 
sutikimų nei 2011 m. tuo pačiu metu. Taigi, Tarnybos vykdomos funkcijos po 2012 m. sausio 1 d. įsigaliojusių VPI pakeitimų išsiplètė, augo ir žmogiškujjų išteklių poreikis, tačiau pastebėtina, kad pareigybių skaičius Tarnyboje mažai kito per pastaruosius metus.

Pažymètina, kad VPI numato Tarnybai 17 funkcijų, taip pat Tarnyba turi atlikti kitų teisès aktų nustatytas funkcijas. Išanalizavus visas Tarnybos vykdomas funkcijas, darytina išvada, kad Tarnybai iš tikrųjų priskirta daug skirtingų funkcijų, todèl tikslinga, kad būtų nustatytos prioritetinès veiklos sritys ir atitinkamai paskirstyti žmogiškieji ištekliai, todèl siūlytina apsvarstyti, ar nèra tikslinga atsisakyti kai kurių funkcijų (pavyzdžiui, kai kurių sutikimų išdavimo ir vykdant pirkimus neskelbiamų derybų būdu, nes pačios perkančiosios organizacijos yra atsakingos už šio pirkimo būdo pasirinkimą, todèl visada kontroliuojančioms institucijoms, prireikus, privalo pateikti argumentus dèl tokio pirkimo būdo pasirinkimo). Svarstytina, ar nepakaktų numatyti perkančiosioms organizacijoms pareigą visuomet Tarnybai pateikti argumentus dèl tokio pirkimo būdo pasirinkimo (kaip ir atliekant pirkimą pagal VPI 56 straipsnio 1 dalies 4 punktą). Tokiu atveju Tarnyba galètų vykdyti išankstinę viešųjų pirkimų kontrolę (a priori). Manytina, kad toks kontrolès mechanizmas galètų būti veiksmingas.

\section{Neskelbiamų derybų vykdymo ypatumai dèl ypatingos skubos ir nenumatytų îvykių (VPI 56 straipsnio 1 dalies 4 punktas)}

Klasikinio sektoriaus direktyva ${ }^{28}$ numato, kad, skelbdama apie sutarties sudarymą, perkančioji organizacija praneša apie pasirinktos sutarties sudarymo procedūras. Jei derybų procedūra vykdoma neskelbiant apie pirkimą, pateikiamas pateisinimas.

VPI 56 straipsnio 1 dalies 4 punkte numatyta, kad pirkimą neskelbiamų derybų būdu galima vykdyti, jeigu neišvengiamai būtina pirkimą atlikti ypač skubiai dèl ịvykio, kurio perkančioji organizacija negalejo numatyti, kai tokio pirkimo neįmanoma atlikti atviro, riboto konkurso ar skelbiamų derybų būdais šiame ịstatyme nustatytais terminais. Aplinkybès, kuriomis grindžiama ypatinga skuba, jokiu būdu negali priklausyti nuo perkančiosios organizacijos. Taigi, VPI ịtvirtintos itin griežtos sąlygos pirkimą vykdyti neskelbiamų derybų būdu.

Prancūzijos Viešųjų pirkimų kodekso ${ }^{29} 35$ straipsnyje numatyta, kad neskelbiamos derybos gali būti vykdomos esant nenumatytoms aplinkybėms ir ypatingai skubai, kai vykdymo sąlygos nèra suderinamos su terminais, numatytais ịprastinems pirkimo procedūroms vykdyti, ir būtent skirti spręsti ypatingos skubos situacijoms, susijusioms su technologijų ar natūraliomis nelaimèmis. 
Pagal susiformavusią ETT praktiką neskelbiamų derybų procedūra minètu pagrindu (VPİ 56 straipsnio 1 dalies 4 punktas) gali būti taikoma tik tada, kai patenkinamos trys kumuliacinès (taikomos kartu) sąlygos:

a) turi ịvykti nenumatytas ịvykis;

b) turi susiklostyti ypatingos skubos aplinkybès, dèl kurių neįmanoma laikytis kitoms procedūroms nustatytų terminų;

c) turi būti priežastinis ryšys tarp nenumatyto įvykio ir dèl to atsiradusios ypatingos skubos.

Sue Arrowsmith taip pat pabrèžia, jog direktyva reikalauja, jog îvykiai būtų „nenumatyti“" norint taikyti neskelbiamų derybų būdą, t. y. kai dèl nenumatytų ịvykių atsiranda ypatingos skubos priežastys, dèl kurių neįmanoma laikytis numatytų terminų pirkimo procedūroms atlikti ${ }^{30}$.

LAT praktikoje remiasi Europos Komisijos parengtu vadovu dèl Bendrijos taisyklių, taikomų viešojo darbų pirkimo sutartims sudaryti, kurioje nenumatytais ịvkiais reikètų laikyti tokius, kurie „neapsakomai viršija ịprastines ekonominio ir socialinio gyvenimo ribas, pavyzdžiui, žemès drebejjimai ar potvyniai ${ }^{\text {“31 }}$.

Kita vertus, pabrežtina, kad neskelbiamų derybų procedūra leidžiama tik tiems darbams, kurie neišvengiamai būtini siekiant nedelsiant reaguoti ị šiuos nenumatytus ịvykius. Lietuvos Aukščiausiojo Teismo (toliau - LAT) teisèjų kolegija vienu iš atvejų nusprendè, kad Lietuvos Respublikos Vyriausybès nutarimas, kuriuo skirtas finansavimas, nelaikytinas privaloma VPI 56 straipsnio 1 dalies 4 punkto taikymo sąlyga. Vyriausybės skiriamas finansavimas per se nelaikytinas nenumatomu ịvykiu, juolab sukeliančiu ypatingą skubą. Vyriausybès veikla negali būti prilyginta nenuspèjamiems ịvykiams, kurie keistų ịprastines viešųjų pirkimų procedūrų taikymo sąlygas. Jei būtų priešingai, ịprastinè Vyriausybės atliekama teisès aktų vykdomoji veikla viešųjų pirkimų teisès prasme taptų ekstraordinariné $\dot{e}^{32}$.

30 Arrowsmith, S. The law of public and utilities procurement, 2005, p. 619. Byla C-385/02, Komisija $v$. Italija. ETT sprendime nurodoma, kad Italijos vyriausybe tvirtino, jog nagrinejamu atveju darbai turèjo būti baigti skubiai, kad nepadidètų potvynių rizika dèl to, kad darbai nebaigti. Antrasis gynybos teisinis pagrindas turi būti suprantamas kaip grindžiamas direktyvos 7 straipsnio 3 dalies c punktu, pagal kuri galimos derybos iš anksto nepaskelbus skelbimo apie sutartị, kai dèl perkančiųjų organizacijų nenumatytų ịvykių atsiranda ypatingos skubos priežastys, dèl kurių neįmanoma laikytis numatytų terminų. Šios nuostatos antrame sakinyje nurodoma, kad aplinkybės, kuriomis remiamasi siekiant pateisinti ypatingos skubos priežastis, neturi atsirasti dèl perkančiųjų organizacijų kaltès. Taigi nagrinėjamu atveju pradinès sutartys dèl darbų, skirtų apsaugai nuo potvynių, buvo sudarytos $1980 \mathrm{~m}$. Be to, nuo pat pradžių buvo numatyta, kad darbai bus vykdomi dalimis pagal turimą finansavimą. Šios aplinkybès nèra ypatingos skubos priežastys. Priešingai, jų atsiradimas priklauso nuo perkančiųjų organizacijų atliekamų veiksmų.

31 Lietuvos Aukščiausiojo Teismo Civilinių bylų skyriaus teisėjų kolegijos 2009 m. lapkričio 13 d. nutartis civilineje byloje Vilniaus miesto apylinkès vyriausiasis prokuroras prieš Vilniaus miesto savivaldybę ir kt. (bylos Nr. 3K-3-505/2009).

32 Lietuvos Aukščiausiojo Teismo Civilinių bylų skyriaus teisèjų kolegijos 2009 m. lapkričio $13 \mathrm{~d}$. nutartis civilineje byloje Vilniaus miesto apylinkès vyriausiasis prokuroras prieš Vilniaus miesto savivaldybę ir kt. (bylos Nr. 3K-3-505/2009). 
Nenumatyto įvykio sąlygą sudètinga konstatuoti. Tą akcentavo ir prancūzų autorius A. Cabanesas pateikdamas tokị pavyzdį: tarkim, reikia ypač skubiai pastatyti mokyklą birželio mėnesị, nes naujų mokslo metų pradžia rugsèjị. Šiuo atveju neaišku, ar ši skuba gali būti motyvuojama nenumatytu ịvykiu. Priešingu atveju pakaktų ramiai laukti ir paskui remtis ypatinga skuba. Taigi, pasirinkus neskelbiamas derybas, labai svarbu įrodyti, kad ypatinga skuba susidarè būtent dèl ịvykių, kurių nebuvo galima numatyti ar suplanuoti iš anksto. A. Cabaneso minimu atveju teigiama, jog skuba yra blogo perkančiosios organizacijos poreikių planavimo rezultatas ${ }^{33}$.

Viename iš Prancūzijos leidinių advokatas S. Nivaultas teigia, kad vykdyti neskelbiamų derybų procedūrą, pavyzdžiui, dẻl audros, kaip nenumatyto îvykio, yra ittikinama. Tačiau konkrečiu atveju teismas pareiškè, kad neskelbiamų derybų vykdymas atogrąžų audros atveju yra neteisètas, kadangi susijusioje geografinèje ir klimatinejje zonoje tropinès audros yra dažnos ir nèra nenumatomos. Kitu atveju buvo pripažinta, kad šio tipo derybų procedūra buvo teisèta, atsižvelgiant ị tai, kad klimatinèje audrų zonoje atsitiko tokios rūšies ir tokio dydžio įvykis, kuris nebuvo numatytas. Kaip visada, perkančiajai organizacijai reikia įrodyti tokių aplinkybių buvimą ${ }^{34}$.

Visais atvejais įstatyme numatytas aplinkybes tenka įrodinèti perkančiajai organizacijai, atsakingai už pirkimą, o priežastys neturi būti susijusios su organizacijos issipareigojimų nevykdymu. Viename iš sprendimų Paryžiaus administracinis teismas išdėstė savo nuomonę, jog konkrečiu atveju skuba buvo susijusi ne su nenumatytais įvykiais, bet su perkančiosios organizacijos ịsipareigojimų nevykdymu, nustatant naujas specifikacijas ir organizuojant naują atvirą konkursą. Šioje situacijoje perkančiąją organizaciją galima kaltinti tik nerūpestingumu ${ }^{35}$. Taigi labai svarbu, kad skuba būtų iš tikrųjų reali ir pagrịsta, atsiradusi dèl nenumatytų ịvykių, o ne tik deklaruojama ir susiklosčiusi dèl perkančiosios organizacijos aplaidumo planuojant pirkimų poreikį.

Atsižvelgiant ị teismų praktiką, nenumatytu ịvykiu galima laikyti tik tokị ar tokias aplinkybes, kurių nebuvo galima numatyti ar išvengti protingai bei atsakingai veikiant perkančiosioms organizacijoms. Ši sąlyga panaši ị Lietuvos Respublikos civiliniame kodekse ${ }^{36}$ (toliau - CK) ịtvirtintą nenugalimos jẻgos (force majeure) apibrèžtị. Nors pastaroji taikoma atsakomybès srityje, tačiau savo esme ji panaši. CK nustatyti force majeure kriterijai. Pirma, sudarius sutarti atsiranda aplinkybès, $k u$ riu nebuvo ja sudarant ir kurių atsiradimo šalis negalejo protingai numatyti. Antra, dèl sudarius sutartị atsiradusių aplinkybių sutarties objektyviai nebegalima vykdyti. Trečia, šalis, neịvykdžiusi sutarties, tų aplinkybių negalèjo kontroliuoti ar negalèjo

33 Cabanes, A. Juris Classeur. Contrats et Marchés Publics 2007, Marchés negociés.

34 Contrats Publics. L'actualité de la commande et des contrats publics N. 84, Janvier 2009. Marchés publics et négociation.

35 Cabanes, A., supra note 32.

36 Lietuvos Respublikos civilinis kodeksas (su pakeitimais ir papildymais). Valstybès žinios. 2000, Nr. 74. 
užkirsti kelio. Ketvirta, sutarties neịvykdžiusi šalis nebuvo prisiemmusi tų aplinkybių atsiradimo rizikos. Sutarčių praktikoje kaip tokios aplinkybės dažniausiai nurodoma karas, sukilimai, riaušès, streikai, stichinès nelaimès (potvyniai, žemès drebejjimai ir pan.) ir t. t. Tačiau kartu atkreipiamas demesys ị tai, kad jeigu sudarant sutartị buvo pakankamai požymių, kad valstybėje, kur reikès vykdyti sutartį, gali kilti karas ir šį̨ aplinkybę buvo galima numatyti, kilęs karas negali būti laikomas force majeure aplinkybe $^{37}$. Kaip ir VPI 54 straipsnio 1 dalies 4 punkto sąlyga, būtina sąlyga - turi ịvykti nenumatytas ịvykis, kurio perkančioji organizacija protingai veikdama negalèjo numatyti, t. y. objektyviai negalima buvo prognozuoti tam tikro ịvykio.

Teismų praktikoje griežtai vertinama, ar tokio pirkimo neįmanoma atlikti atviro ar riboto konkurso ar skelbiamų derybų būdais šiame ịstatyme nustatytais terminais, taip pat ịvertinami terminai, ar perkančioji organizacija pasinaudojo galimybe sutrumpinti terminus VPİ nustatyta tvarka ar pirkimą atlikti pagreitinta ${ }^{38}$ procedūra. Taip pat reikia įrodyti, kad aplinkybės nepriklausė nuo perkančiosios organizacijos. Laikoma, kad ypatingos skubos aplinkybès priklauso nuo perkančiosios organizacijos, jeigu ji pati neleistinai (be pagrisstų objektyvių priežasčių) ilgai užtęsė tam tikrų veiksmų atlikimą, dèl ko kilo ypatingos skubos aplinkybès ${ }^{39}$.

Sue Arrowsmith teigia, kad turbūt didžiausias prioritetas skiriamas sveikatos ir saugumo interesams apsaugoti siekiant išvengti turto žalos, kai neskelbiamų derybų procedūra gali būti pateisinama, tačiau netgi tuo atveju, jei sveikata ir saugumas yra pavojuje, šis pagrindas gali būti paneigtas, jei tikètini nuostoliai dèl delsimo laikotarpio ${ }^{40}$.

Lietuvos teismų ir ETT praktikoje laikomasi pozicijos, kad ypatinga skuba gali būti pagrịsta būtinybe apsaugoti viešąjį interesą, kuris neišvengiamai būtų pažeistas, jeigu nebūtų nedelsiant imtasi atitinkamų priemonių. Viešuoju interesu laikomos priemonės, skirtos apsaugoti žmonių saugumą ir gyvybę (pvz., pastatyti barjerus neišvengiamai ir greitu laiku gresiančioms sniego griūtims sulaikyti) ar sveikatą (pavyzdžiui, užtikrinti nepertraukiamą kraujo komponentų tiekimą ligoninei) ${ }^{41}$.

37 Lietuvos Respublikos civilinis kodekso komentaras. Šeštoji knyga. Prievolių teisè. Pirmas tomas. Vilnius: Justitia, 2003.

38 Europos Teisingumo Teismo 1993 m. rugpjūčio 2 d. sprendimas byloje C-107/92 Commission of the European Communities v. Italian Republic.

39 Vilniaus apygardos administracinio teismo $2011 \mathrm{~m}$. gegužès $2 \mathrm{~d}$. nutartis administracinio teisès pažeidimo byloje Nr. II-380-171/2011.

40 Arrowsmith, S. The law of Public and Utilities procurement, 2005, p. 618. Byloje C-107/902 Generalinis advokatas Gulmannas pažymejjo, kad skubos išimtimi gali remtis, jei šiems interesams daromas poveikis. Byloje C-328/92 ETT išsakè nuomonę, kad derybų procedūra negali būti taikoma tik tam, kad būtų galima užtikrinti tam tikrą medikamentų kiekị, siekiant išvengti jų trūkumo, bet tik tada, kai toks stygius iš tikųjų paaiškejjo.

41 Lietuvos Respublikos viešųjų pirkimų ịstatymo I-III skyrių komentaras [interaktyvus]. Vilnius: Advokatų kontora „LAWIN Lideika, Petrauskas, Valiūnas ir partneriai“ 2012 [žiūrèta 2013-09-01]. <http://www.ukmin.lt/uploads/documents/Viesieji\%20pirkimai/121030_VPI_ IIII_skyri\%C5\%B3_komentaras_fn.pdf $>$. 
Viename iš sprendimų LAT rèmėsi ETT sprendimu, kad aplinkybè, jog valstybės narès institucija, kuri pagal nacionalinę teisę viešųjų darbų projektų aprobacijos procedūros metu privalo pateikti sutikimą dèl konkretaus projekto, prieš tam nustatytą terminą išreiškia savo nepritarimą dèl priežasčių, dèl kurių ji tam turi teisę, nelaikoma nenumatytu ịvykiu ${ }^{42}$. Minimu atveju taip pat pasiremta ir kitu ETT sprendimu, kuriame būtinybès atlikti darbus per nacionalinès institucijos nurodytus terminus teismas nepripažino ypatinga skuba ${ }^{43}$.

Praktikoje pasitaikė atvejų, kai pripažinta, kad ypatingos skubos aplinkybès nepriklauso nuo perkančiosios organizacijos, jeigu jos kyla dèl kito subjekto veiksmų, kuriems perkančioji organizacija negali turèti ịtakos. Tokį atvejị iliustruoja ypatingos skubos aplinkybès, kylančios, pavyzdžiui, dèl to, kad tiekejjas iš esmès netinkamai vykdo pirkimo sutartị su perkančiąja organizacija, ir perkančioji organizacija yra priversta ją nutraukti ${ }^{44}$.

Lietuvos vyriausiasis administracinis teismas (toliau - LVAT), nagrinėdamas bylą dèl VPI 73 straipsnio 1 dalies 4 punkto taikymo (pirkimą vykde komunalinio sektoriaus perkančioji organizacija), nustatè, kad, kaip ir pažymejjo pirmosios instancijos teismas, norėdamas remtis aplinkybe, kad ypatinga skuba buvo būtina dèl numatyto termino įvykdymo, pareiškẻjas turejjo pateikti apskaičiavimus ar kitus dokumentus (pavyzdžiui, dèl reikalingų ịrenginių unikalumo, gamybos pagal atskirą užsakymą, ilgų pateikimo terminų nuo užsakymo gavimo ar statybos technologinių procesų, kad darbus reikalinga atlikti tam tikrais etapais, tarp kurių būtinos pertraukos, ir pan.), patvirtinančius, kad nebūtų galëjęs atlikti darbų, tačiau toks faktas nebuvo įrodytas. Nagrinejjamu atveju aplinkybės, kuriomis grindžiama ypatinga skuba, susidarè dèl ịvykio, kurị perkančioji organizacija galèjo ir turèjo numatyti, kadangi šios aplinkybès susidarè būtent dèl neteisètų perkančiosios organizacijos veiksmų (vykdydama atvirą konkursą, ji pažeidè VPI nuostatas), todèl buvo pažeistos VPI 73 straipsnio 1 dalies 4 punkto nuostatos ${ }^{45}$. LVAT praktikoje pažymima, kad nenumatytu pripažĭstamas tik toks ịvykis, kuris ịvyko be perkančiosios organizacijos veiksmų ir kurio protingai bei atsakingai veikiantis subjektas negalejo numatyti.

Ch. Bovis ${ }^{46}$ taip pat pabrěžia, kad ypatingos skubos sutarties sudarymas neskelbiamų derybų būdu neturi priklausyti nuo perkančiosios organizacijos, ir nurodo, kad organizacinės perkančiosios organizacijos problemos ar vidinès aplinkybès negali būti pateisinamos skubos poreikiu.

Paminètina ir tai, jog ETT byloje C-525/03 Komisija prieš Italiją, Generalinis advokatas F. G. Jacobsas išvadoje teigè, jog kaip bendro pobūdžio teiginys atrodo

Byla 318/94, Rink. p. I-1949. Šią poziciją Teisingumo Teismas patvirtino ir vèlesneje praktikoje, byla C-394/02, Rink. 2005.

43 Byla C-394/02, Rink. 2005, p. I-4713.

44 Lietuvos apeliacinio teismo $2012 \mathrm{~m}$. birželio 29 d. nutartis civilineje byloje Nr. 2A-1852/2012.

45 Lietuvos vyriausiojo administracinio teismo $2012 \mathrm{~m}$. gruodžio $18 \mathrm{~d}$. nutartis administracinèje byloje Nr. A ${ }^{552}-3164 / 2012$.

Bovis, Ch. EU public procurement law. E. Elgar, 2007, p. 251, 252. 
nenuginčijama, kad masinis gaisrų protrūkis gali būti ypatingos skubos priežastis, dèl kurios reikia ịsigyti kovos su gaisrais paslaugas ir ịrangą, jei jų dar neturima pakankamai. Europos Komisija neginčijo šio teiginio, bet mano, kad laikomasi ne visų nukrypti leidžiančios nuostatos taikymo sąlygų. Viena vertus, miško gaisrų protrūkiai vasarą yra nuolat pasikartojantis ịvykis Pietų Europoje, todèl jie numatytini, o ịsigyti bet kokia skuba priemones kovai su jais priklauso Italijos institucijoms. Kita vertus, ginčijamas potvarkis liko galioti pasibaigus nacionalinei nepaprastajai padečiai 2002 m. spalio $31 \mathrm{~d}$. ir šitaip galèjo būti taikomas leidžiant derybas po to, kai skubos situacijos nebeliko. Advokatas F. G. Jacobsas sutiko, kad nuolatiniai sezoniniai ịvykiai negali būti laikomi ịvykiais, kurių negalima numatyti, tačiau dèl to negalima paneigti, kad net tokie ịvykiai per keletą metų gali tapti tokie išskirtinai intensyvūs arba tokios apimties, jog teisètai galètų būti laikomi ịvykiais, negalimais numatyti ${ }^{47}$.

Atkreiptinas demesys ị tai, kad neskelbiamų derybų būdu gali būti sudaroma sutartis tik laikotarpiui, kol vyksta (egzistuoja) nenumatyti invkiai, ir tik tokia apimtimi, kuri būtina ir yra suponuota šių ịvykių, o nenumatytam ịvykiui pasibaigus, turètų būti sudaroma (jei yra poreikis) nauja sutartis, ịvykdžius naują pirkimą ịprastiniu VPİ numatytu pirkimo būdu.

4. Neskelbiamų derybų vykdymas, kai negauta pasiūlymų arba nėra tinkamų pasiūlymų, arba visi nepriimtini, ar neatitiko sąlygų (VPI 56 straipsnio 1 dalies 2 punkto pagrindu)

VPI 56 straipsnio 1 dalies 2 punkte numatyta, kad vykdyti viešuosius pirkimus neskelbiamų derybų būdu galima, jei paskelbus atvirą ar ribotą konkursą, apskritai nebuvo gauta pasiūlymų arba nebuvo gauta tinkamų pasiūlymų, o pirminès pirkimo sąlygos iš esmés nekeičiamos, ir jei Europos Komisijos prašymu jai pateikiama šiuo pagrindu atliekamo ar atlikto pirkimo ataskaita (taikoma, kai pirkimus vykdo klasikinio sektoriaus perkančiosios organizacijos ${ }^{48}$.

Didelių problemų nekyla tuo atveju, jei apskritai nebuvo gauta nẻ vieno pasiūlymo ar nebuvo pateikta né vienos paraiškos, tačiau VPI 56 straipsnio 1 dalies 2 punkte numatytas atvejis, kai paskelbus atvirą ar ribotą konkursą, nebuvo gauta tinkamu pasiūlymų.

VPI 73 straipsnio 1 dalies 1 punktas detalizuoja: jeigu atvirame, ribotame konkurse ar skelbiamose derybose nebuvo pateikta nè vienos paraiškos arba nebuvo né

47 Generalinio advokato Franciso Geoffrey Jacobso 2005 m. birželio 2 d. išvada byloje C-525/03, Commission of the European Communities v. Italian Republic.

48 VPI 73 straipsnio 1 dalies 1 punktas numato, jei atvirame ar ribotame konkurse ar skelbiamose derybose nebuvo pateikta nè vienos paraiškos arba nẻ vieno pasiūlymo, arba nebuvo nẻ vieno tinkamo (atitinkančio keliamus reikalavimus, kurie būtini perkančiosios organizacijos poreikiams patenkinti) pasiūlymo, o pirkimo sąlygos iš esmès nekeičiamos (taikoma, kai pirkimus vykdo komunalinio sektoriaus perkančiosios organizacijos). 
vieno tinkamo (atitinkančio keliamus reikalavimus, kurie būtini perkančiosios organizacijos poreikiams patenkinti) pasiūlymo, t. y. keliamus reikalavimus atitinkančio pasiūlymo, kurie būtini patenkinti perkančiosios organizacijos poreikius ${ }^{49}$.

S. Nivaultas ${ }^{50}$ teigia, kad netinkamas pasiūlymas yra nereikalingas pasiūlymas. Pavyzdžiui, perkančioji organizacija perka biuro kompiuterius, o gauna pasiūlymą dèl nešiojamųjų kompiuterių. Panašiai gali būti siūlomi didelio galingumo lèktuvai, nors perkančiosios organizacijos poreikiai buvo mažo galingumo lèktuvų pirkimas.

Europos Komisija vienoje iš bylų ${ }^{51}$ teigè, kad kaip „netinkamas“ galètų būti kvalifikuojamas tik toks pasiūlymas, kurio dalykas visiškai skiriasi nuo aprašytojo skelbime apie pirkima. Komisijos nuomone, tarp pasiūlymo nebuvimo ir netinkamo pasiūlymo egzistuoja ryšys, nes kiekviena iš šių situacijų pakeičia kitą kaip tiesioginio sutarties sudarymo pagrindas, abiem atvejais su atitinkamo projekto igyvendinimu susiję poreikiai nèra tenkinami.

ETT išnagrinèjus aukščiau minėtą bylą, kurioje buvo pareikštas Europos Komisijos ieškinys prieš Graikijos Respubliką, buvo paaiškinta „netinkamo pasiūlymo“ sąvoka, t. y. jog pasiūlymai turi būti kvalifikuojami kaip „netinkami“, jei pateiktų pasiūlymų ir tokių specifikacijų neatitiktis neleidžia perkančiajai organizacijai tinkamai igyvendinti projekto, dèl kurio pradèta viešojo pirkimo procedūra. Tokia neatitiktis nèra tik paprastas netikslumas ar maža detalè, o atvirkščiai, turi būti laikoma, kad dèl jos pasiūlymai negali patenkinti perkančiosios organizacijos poreikių ${ }^{52}$. Šioje byloje buvo pateikta Generalinio Advokato P. Madure`o pozicija, jog Graikijos Vyriausybès žodžio „netinkamas“ platus aiškinimas yra nepriimtinas. P. Madure‘o nuomone, perkančiųjų organizacijų teisė atmesti „netinkamus“ pasiūlymus dèl smulkių netikslumų iš esmès reiškia, kad joms yra suteikiama labai didelè diskrecija nuspręsti, ar skelbti konkursą, ar ne. Perkančioji organizacija, norèdama „proteguoti dalyvius“, kaip sprendime Ordine degli Architetti suformulavo ETT, gali lengvai nustatyti, dèl ko pateiktas pasiūlymas neatitinka sutarties specifikacijų, ji atmesti kaip „netinkamą" ir sudaryti sutartị prieš tai nesurengusi kandidatų varžymosi gauti naujus pasiūlymus. Europos Komisija buvo pateikusi aiškinimą, kad „netinkamas“ pasiūlymas gali būti atmestas, o perkančioji organizacija gali neskelbti konkurso tik tokiu atveju, jeigu pasiūlymas negali patenkinti organizacijos poreikių, palieka perkančiajai organebuvo gauta né vieno „keliamus reikalavimus atitinkančio pasiūlymo“. Pažymėtina, kad VPI 73 straipsnio 1 dalies 1 punktas taikomas, kai pirkimą atlieka komunalinio sektoriaus perkančioji organizacija. Nurodytomis VPİ nuostatomis igyvendinamos Klasikinio sektoriaus direktyvos 31 straipsnio 1 dalies a punkto („nebuvo pateikta tinkamų pasiūlymų“) ir Komunalinio sektoriaus direktyvos 40 straipsnio 3 dalies a punkto („nebuvo gauta tinkamų pasiūlymų“) nuostatos.

50 Contrats Publics. L'actualité de la commande et des contrats publics N. 84, Janvier 2009. Marchés publics et négociation. Le Moniteur.

51 Europos Komisijos ieškinys prieš Graikijos Respubliką (byla C-250/07).

52 Ibid. 
nizacijai užtektinai diskrecijos ịvertinti pateiktą pasiūlymą ir užtikrinti, kad nebūtų apeiti Bendrijos viešųų pirkimų taisyklių reikalavimai ${ }^{53}$.

Pažymėtina, kad rengiant naujos direktyvos projektą buvo mėginta paaiškinti netinkamo pasiūlymo sąvoka ir buvo numatyta, kad pasiūlymas laikomas netinkamu, jeigu jis neturi jokios reikšmès sutarčiai, nes, nepadarius esminiu pakeitimu, negali patenkinti pirkimo dokumentuose nurodytu perkančiosios organizacijos poreikiu ir reikalavimu ${ }^{54}$, tačiau $2014 \mathrm{~m}$. vasario 26 d. priimtos direktyvos ${ }^{55}$ tekste šių nuostatu neliko.

\section{Pranešimas dèl savanoriško ex ante skaidrumo}

Tarnybos sutikimas nereikalingas, jeigu perkančioji organizacija numato paskelbti pranešimą dèl savanoriško ex ante (lot. iš anksto) skaidrumo ${ }^{56}$ ir informaciją apie tai nurodo pirkimo dokumentuose arba jeigu pirkimas atliekamas pagal 56 straipsnio 1 dalies 4 punktą. Ex ante (išankstinio) skelbimo tikslas - užtikrinti savanorišką išankstinị skaidrumą, kaip nurodyta direktyvų 89/665/EEB ir 92/13/ EEB dèl teisių gynimo priemonių 2d straipsnio 4 dalyje ir direktyvos 2009/81/EB 60 straipsnio 4 dalyje (informacija apie sutarties sudarymą iš anksto nepaskelbus skelbimo apie pirkimą Europos Sąjungos oficialiajame leidinyje).

Šių skelbimų teikimas yra savanoriškas ir neprivalomas perkančiosioms organizacijoms. Šis skelbimas teikiamas perkančiajai organizacijai priẻmus sprendimą sudaryti pirkimo sutartị, tačiau iki sutarties sudarymo ${ }^{57}$.

Taigi, pirmiausia perkančioji organizacija pasirenka neskelbiamų derybų būdą ir atlieka pirkimą, paskui skelbiamas savanoriškas ex ante pranešimas iki sutarties sudarymo. Pažymètina, kad Tarnybos sutikimo nereikia tuo atveju, jeigu perkančioji organizacija pirkimo dokumentuose numato galimybę skelbti pranešimą dèl savanoriško ex ante skaidrumo (VPI 24 straipsnio 2 dalies 24 punktas).

Nors paskelbus savanorišką ex ante pranešimą Tarnybos sutikimas nereikalingas, tačiau Taisyklių 5 punktas numato, kad Tarnyba priima perkančiụjų organizacijų teikiamus pagrindimus dèl İstatymo 56 straipsnio 1 dalies 4 punkte nustatytos išimties taikymo ir dèl pirkimo neskelbiamų derybų būdu İstatymo 56 straipsnyje numatytais pagrindais vykdymo, kai perkančioji organizacija paskelbia pranešimą dèl savanoriš-

53 Generalinio advokato M. Poiareso Maduro 2008 m. gruodžio 14 d. išvada byloje C-250/07, Europos Bendriju Komisija prieš Graikijos Respubliką.

54 Pasiūlymas Europos Parlamento ir Tarybos direktyva dèl viešųjų pirkimų /* KOM/2011/0896 galutinis - 2011/0438 (COD) [interaktyvus]. [žiūrèta 2013-09 -01]. </http://eurlex.europa.eu/ LexUriServ/LexUriServ.do?uri=COM:2011:0896:FIN:LT:HTML>

55 [interaktyvus]. [žiūrèta 2015-01 -09]. < http://eur-lex.europa.eu/legal-content/LT/TXT/HTM L/?uri=OJ:JOL_2014_094_R_0065_01\&from=LT>.

56 [interaktyvus]. [žiūrèta 2013-09 -01]. < http://simap.europa.eu/docs/simap/pdf_jol/lt/sf_015_ lt.pdf $>$.

57 Lietuvos Respublikos viešųjų pirkimų ịstatymo I-III skyrių komentaras, supra note 40. 
ko ex ante skaidrumo ir tai nurodo pirkimo dokumentuose, ir juos nagrineja, siekdama ịvertinti teisès aktais nustatytų reikalavimų parenkant pirkimo būdą pažeidimų riziką. Pažymėtina, kad Taisyklèse taip pat numatyta, kad perkančioji organizacija, priemusi sprendimą pirkimą atlikti neskelbiamų derybų būdu, kai numato paskelbti pranešimą dèl savanoriškojo ex ante skaidrumo, nedelsdama, bet ne vèliau kaip per 5 darbo dienas Tarnybai teikia pagrindimą, kuriame nurodo išsamius argumentus, kad atsirado İstatymo 56 straipsnio atitinkamoje dalyje ir punkte nustatyti pagrindai.

Pranešimas dèl savanoriško ex ante skaidrumo turètų būti paskelbtas ne vèliau kaip prieš 10 kalendorinių dienų iki viešojo pirkimo sutarties sudarymo. Manytina, kad šis terminas numatytas dèl to, kad suinteresuoti pirkimu asmenys galètų pateikti pretenzijas dèl tokios sutarties sudarymo.

Pažymètina, kad teismas negali pripažinti pirkimo sutarties negaliojančia, jeigu yra tenkinamos visos VPI $95^{1}$ straipsnio 3 d. nurodytos sąlygos ${ }^{58}$. Minètos VPI nuostatos priimtos igyvendinant $2007 \mathrm{~m}$. gruodžio $11 \mathrm{~d}$. Europos Parlamento ir Tarybos direktyvos 2007/66/EB, iš dalies keičiančios Tarybos direktyvas 89/665/EEB ir 92/13/ EEB dèl viešųjų sutarčių suteikimo peržiūros procedūrų veiksmingumo didinimo reikalavimus (2 d. straipsnio 4 dalis).

Pažymètina, kad išankstinis paskelbimas (pranešimas dèl savanoriško ex ante skaidrumo) nereiškia savaiminio skaidrumo, tai daugiau perkančiosios organizacijos apsidraudimas, nes VPI numatyta, jog tokia sutartis, jei tenkinamos VPI numatytos sąlygos, negali būti pripažinta negaliojančia, tačiau visada perkančiajai organizacijai svarbu tinkamai VPĮ nustyta tvarka pasirinkti pirkimo būdą, nes išlieka galimybe teismui taikyti alternatyvias sankcijas, numatytas VPI ${ }^{59}$. Be to, pažymètina tai, kad pirmiausia perkančioji organizacija privalo pagrịsti savo sprendimą, kodẻl ịstatymu leidžiama nepaskelbti apie tarptautinès vertės pirkimą Europos Sąungos oficialiajame leidinyje.

58 Teismas negali pripažinti pirkimo sutarties negaliojančia pagal šio straipsnio 1 dalies 1 punktą (perkančioji organizacija sudaré pirkimo sutartị nepaskelbusi apie tarptautinès vertès pirkimą Europos Sąjungos oficialiajame leidinyje arba nepaskelbusi apie supaprastintą pirkimą, kai tai néra leidžiama pagal šio ịstatymo reikalavimus), jeigu yra visos šios sąlygos: 1) perkančioji organizacija nusprendè, kad šiuo ịstatymu leidžiama nepaskelbti apie tarptautinès vertès pirkimą Europos Sąjungos oficialiajame leidinyje arba nepaskelbti apie supaprastintą pirkimą; 2) perkančioji organizacija paskelbẻ pranešimą dèl savanoriško ex ante skaidrumo (tarptautinès vertès pirkimo atveju) ar informacinị pranešimą; 3) pirkimo sutartis buvo sudaryta ne anksčiau kaip po 10 dienų nuo pranešimo dèl savanoriško ex ante skaidrumo paskelbimo dienos arba ne anksčiau kaip po 5 darbo dienų nuo informacinio pranešimo paskelbimo dienos.

59 Žr. [interaktyvus]. [žiūrèta 2013-09-01]. - <http://www.lrs.lt/pls/proj/dokpaieska.showdoc_ 1 ?p_id=8267\&p_query=vie\%F0\%F8j\%F8\%20pirkim\%F8\%20ex\%20ante\&p_tr2=2\&p_ fix $=n \& p \_g o v=n>$. Aiškinamajame rašte Ūkio ministerija nurodo, kad, pavyzdžiui, pirkimo sutartis, sudaryta neteisetai nepaskelbus apie pirkimą, turi būti laikoma galiojančia, jeigu perkančioji organizacija prieš 10 dienų (supaprastintų pirkimų atveju - prieš 5 dienas) iki pirkimo sutarties sudarymo paskelbẻ pranešimą dèl savanoriško ex ante skaidrumo. İstatymo projekte nustatytais atvejais vietoj viešojo pirkimo sutarties pripažinimo negaliojančia turès būti taikomos alternatyvios sankcijos (baudos perkančiajai organizacijai arba sutarties trukmès sutrumpinimas). 
Europos Sąungos teisès normų aiškinimo kontekste svarbu pažymėti, kad $2013 \mathrm{~m}$. sausio 15 d. ETT buvo pateiktas Consiglio di Stato (Italija) prašymas priimti prejudicinị sprendimą byloje Ministero dell'Interno prieš Fastweb SpA (byla C-19/13) ${ }^{60}$. Buvo pateiktas prejudicinis klausimas: ar direktyvos Nr. 2007/66 (1) 2d straipsnio 4 dalị reikia aiškinti taip, kad, kai perkančioji organizacija prieš sudarydama sutarti tiesiogiai su konkrečiu ūkio subjektu, pasirinktu neskelbiant pranešimo apie pirkimą, Europos Sąjungos oficialiajame leidinyje paskelbia pranešimą dèl savanoriško ex-ante skaidrumo ir pasirašo sutartị tik praejjus bent dešimčiai dienų nuo šio paskelbimo, nacionaliniam teismui automatiškai visais atvejais draudžiama pripažinti sutartị negaliojančia, net jeigu nustatoma, kad buvo pažeistos nuostatos, pagal kurias tam tikrais atvejais leidžiama sudaryti sutartị nerengiant viešojo pirkimo procedūros? Šiuo konkrečiu atveju ETT ${ }^{61}$ pasisaké, kad direktyvos 89/665 2d straipsnio 4 dalis aiškintina taip, kad kai viešojo pirkimo sutartis sudaryta nepaskelbus apie pirkimą Europos Sajungos oficialiajame leidinyje, nors pagal direktyvą 2004/18 tai neleidžiama, pagal šią nuostatą ši sutartis negali būti pripažinta negaliojančia, jeigu ìvykdytos joje numatytos sąlygos, o tai turi patikrinti prašymą priimti prejudicinị sprendimą pateikęs teismas. ETT pažymèjo, kad turi būti aiškiai ir nedviprasmiškai atskleistos priežastys, dèl kurių perkančioji organizacija nusprendè, kad gali sudaryti sutartị neskelbdama apie pirkimą. Taigi pirmiausia reikia išsiaiškinti, ar perkančioji organizacija galejo taikyti numatytą derybų procedūrą. Taigi ETT iš esmès dar kartą pabrèžè, kad neskelbiamų derybų procedūra gali būti taikoma tik išimtiniais teisès aktuose nustatytais atvejais, o tais atvejais, kai šių reikalavimų nepaisoma, t. y. direktyvos 89/665 2d straipsnio 4 dalyje numatytos sąlygos neįvykdytos - būtų galimybè pripažinti sutarti negaliojančia ir tiekejjams, iš kurių neteisètai buvo atimta galimybè konkuruoti, tokia galimybè suteikiama.

Atkreiptinas dèmesys ị tai, kad $2011 \mathrm{~m}$. atlikdama tyrimą ${ }^{62}$, straipsnio autorè prašè nurodyti pagrindines priežastis, dẻl kurių perkančiosios organizacijos neskel-

60 [interaktyvus]. [žiūrèta 2013-09-01]. <http://eurlex.europa.eu/LexUriServ/LexUriServ.do?uri=OJ:C:2013:086:0011:0011:LT:PDF>. Jeigu i̇ prejudicinį klausimą būtų atsakyta taip, kad $2 \mathrm{~d}$ straipsnio 4 dalimi reikalaujama išsaugoti sutartị galiojančią visais atvejais ir kad valstybès narès negali numatyti kitų nuostatų, kyla klausimas, ar toks sprendimas atitinka tam tikrus iš Sutarties dèl Europos Sąjungos veikimo kylančius principus, šiuo atveju — šalių lygybès, nediskriminavimo ir konkurencijos apsaugos principus, ir Europos Sąjungos pagrindinių teisių chartijos 47 straipsnyje ịtvirtintą teisę ị teisingą bylos nagrinejjimą.

61 [interaktyvus]. [žiūrèta 2015-01-09]. <http://curia.europa.eu/juris/liste.jsf?language=en\&num $=\mathrm{C}-19 / 13>$.

62 Minètas tyrimas atliktas 2011-01-10-2011-03-25. $2011 \mathrm{~m}$. sausio 10-15 d. respondentams buvo išsiųstas elektroninis laiškas, kuriame nurodytas apklausos prieigos adresas, ir prašoma atsakyti ị anketoje pateiktus klausimus. Iš viso buvo išsiųsta 5000 elektroninių laiškų. 2011-0325 apklausa baigta, o pirminiai duomenys surinkti ir parengti statistinei analizei. Tyrimui buvo atrinkta apie 5000 respondentų - Lietuvos institucijų, i̇monių bei organizacijų ir kitų subjektų, turinčių perkančiosios organizacijos statusą ir privalančių atlikti viešuosius pirkimus pagal VPI numatytas procedūras. Respondentų buvo prašoma nurodyti pagrindines priežastis, dèl 
bia pranešimo dèl ex ante skaidrumo. Tyrimo metu paaiškejjo, kad tik nedidelè dalis perkančiųjų organizacijų nurodė skelbianti pranešimą dèl savanoriško ex ante skaidrumo. Pažymėtina, kad tyrimas atliktas dar negaliojat VPI ịstatymo nuostatai, kai Tarnybos sutikimas nereikalingas, jeigu perkančioji organizacija numato paskelbti pranešimą dèl savanoriško ex ante skaidrumo ir informaciją apie tai nurodo pirkimo dokumentuose arba jeigu pirkimas atliekamas pagal 56 straipsnio 1 dalies 4 punktą.

Tikètina, kad perkančiosios organizacijos išankstinio skelbimo neskelbia dèl informacijos trūkumo ar dèl to, kad nèra specialių mokymų ir pakankamai aiškios informacijos dèl šios ịstatymo normos taikymo.

\section{Išvados ir pasiūlymai}

1. Pažymėtina, kad VPI detaliai reguliuoja neskelbiamų ir skelbiamų derybų vykdymą. VPI 57 straipsnio 2 dalis numato, kad, derèdamasi su tiekèjais, perkančioji organizacija siekia geriausio rezultato ir pagal derybų rezultatus bei pirkimo dokumentuose nustatytus vertinimo kriterijus nustato geriausia pasiūlyma. Manytina, kad geriausias pasiūlymas - tai ne tik perkančiosios organizacijos poreikius ir reikalavimus atitinkantis pasiūlymas, bet ir siekis derybų metu susitarti dèl maksimaliai geriausios kainos ir kitų palankiausių pirkimo sąlygų.

2. Dèl neskelbiamų derybų procedūros vykdymo specifiškumo svarbu kiekvienu konkrečiu atveju ịvertinti pirkimo pasirinkimo procedūros pagrịstumą bei derybų procedūrą vykdyti ypač atsakingai, laikantis konfidencialumo, lygiateisiškumo ir skaidrumo reikalavimų, užtikrinant sąžiningą dalyvių konkurenciją ir viešąj interesą.

3. Pasirenkant neskelbiamas derybas vykdyti VPI 56 straipsnio 1 dalies 4 punkto pagrindu labai svarbu, kad skuba būtų iš tikrųjų reali ir pagrịsta, atsiradusi dèl nenumatytų ịvykių, o ne deklaruojama, pavyzdžiui, dèl perkančiosios organizacijos aplaidumo planuojant pirkimų poreikį ar neveiklumo.

4. Kaip minèta, nèra aišku, kokią atsakomybę turètų prisiimti Tarnyba, jeigu teismas pripažintų negaliojančia sutartị, kuri sudaryta neteisėtai atlikus neskelbiamas derybas, gavus Tarnybos sutikimą. Todèl siūlytina VPI numatyti Tarnybos atsakomybę tokiu atveju, jei teismas sutartị pripažintų negaliojančia gavus Tarnybos sutikimą pirkimą vykdyti neskelbiamų derybų būdu, arba apsvarstyti galimybę atsisakyti, kad pirkimams vykdyti neskelbiamų derybų būdu reikalingas Tarnybos sutikimas. Svarstytina, ar nepakaktų numatyti perkančiosioms organizacijoms pareigą Tarnybai

kurių perkančiosios organizacijos neskelbia pranešimo dèl ex ante principo, ex ante skaidrumo. Respondentai nurodè tokias pagrindines priežastis, dèl ko neskelbia ex ante pranešimo: neužtenka laiko metiniam pirkimų planui sudaryti, derinti, paskelbti, procedūroms ir sutarčiai ịvykdyti per vieną ataskaitinị laikotarpị. Be to, užsienio tiekejjai nedalyvauja konkursuose, procedūra sudètinga ir pirkimo būdas nenustatomas, netinkamas pirkimų planavimas, trūksta aiškumo, nęivertinama rizika ir pasekmès. Tai naujas reikalavimas, o kai skelbiamas skelbimas, to daryti neprivaloma. 
pateikti visais atvejais tik pagrindimą dèl neskelbiamų derybų, kaip pirkimo būdo pasirinkimo (kaip ir atliekant pirkimą pagal VPI 56 straipsnio 1 dalies 4 punktą). Tokiu atveju Tarnyba galètų vykdyti išankstinę (a priori) viešųjų pirkimų kontrolę. Manytina, kad toks kontrolès mechanizmas galètų būti veiksmingas.

5. Išankstinis paskelbimas (pranešimas dèl savanoriško ex ante skaidrumo) nereiškia savaiminio skaidrumo, tai daugiau perkančiosios organizacijos apsidraudimas, nes VPI numatyta, jog tokia sutartis tam tikrais atvejais (kai tenkinamos VPI numatytos sąlygos) negali būti pripažinta negaliojančia, tačiau visada perkančiajai organizacijai svarbu tinkamai, VPİ nustatyta tvarka, pasirinkti pirkimo būdą. Siūlytina Tarnybai parengti informacinị pranešimą dèl išankstinio (ex ante) pranešimo skelbimo ypatumų ir jo taikymo praktikos.

\section{Literatūra}

Ambrazevičienė, R. Teisètumo užtikrinimo priemonès vykdant viešuosius pirkimus. Jurisprudencija. 2003, 46(38).

Arrowsmith, S. The Law of Public and Utilities Procurement. London: Sweet and Maxwell, 2005.

Byla 84/03, Commission of European Communities v. Kingdom of Spain [1984].

Byla C-57/94, Commission v. Italy [1995], ECR-I-1249.

Byla C-450/06, Varec SA v. Belgium, Diehl Remschied GmbH \& Co. 2008.

Cabanes, A. Juris Classeur Contrats et Marchés Publics 04, 2007, Marchés negociés.

Code des marchés publics [interaktyvus]. [žiūrèta 2013-09-01]. <http://www. legifrance.gouv.fr $>$.

Contrats Publics. L'actualité de la commande et des contrats publics $\mathrm{N}$. 84, Janvier 2009. Marchés publics et négociation. Le Moniteur.

Dabartinés lietuviu kalbos žodynas. Vyr. red. S. Keinys. Vilnius: Mokslo ir enciklopedijų leidybos institutas, 2012.

Diržytè, A.; Sondaitè, J.; Norvilè, N. Verslo psichologija. Vilnius: Mykolo Romerio universitetas. 2012.
Europos Bendrijų Teisingumo Teismo $1996 \mathrm{~m}$. kovo $28 \mathrm{~d}$. sprendimas byloje C-318/94, Komisija prieš Vokietija. Europos Bendrijų Teisingumo Teismo $2005 \mathrm{~m}$. birželio $2 \mathrm{~d}$. sprendimas byloje C-394/0, Komisija prieš Graikija.

Europos Bendriju Teisingumo Teismo $2005 \mathrm{~m}$. birželio $2 \mathrm{~d}$. sprendimas byloje C-394/02, Komisija prieš Graikija.

Europos Sąungos Teisingumo Teismo $2011 \mathrm{~m}$. spalio $27 \mathrm{~d}$. sprendimas byloje C-601/10, Europos Komisija prieš Graikijos Respublika.

Generalinio advokato M. Poiareso Maduro $2008 \mathrm{~m}$. gruodžio $14 \mathrm{~d}$. išvada byloje C-250/07, Europos Bendriju Komisija prieš Graikijos Respubliką.

Generalinio advokato Franciso Geoffrey Jacobso $2005 \mathrm{~m}$. birželio $2 \mathrm{~d}$. išvada byloje C-525/03, Commission of the European Communities v. Italian Republic.

Lietuvos Aukščiausiojo Teismo Civilinių bylų skyriaus teisèjų kolegijos $2009 \mathrm{~m}$. lapkričio $13 \mathrm{~d}$. nutartis civilineje byloje Vilniaus miesto apylinkés vyriausiasis prokuroras prieš Vilniaus miesto savivaldybe ir kt. (bylos Nr. 3K-3505/2009). 
Lietuvos apeliacinio teismo $2012 \mathrm{~m}$. birželio 29 d. nutartis civilineje byloje Nr. 2A-1852/2012.

Lietuvos Aukščiausiojo Teismo Civilinių bylų skyriaus teisejjų kolegijos $2012 \mathrm{~m}$. spalio $24 \mathrm{~d}$. nutartis civilineje byloje $B U A B$ LTC prieš Kauno miesto savivaldybès administracija (bylos Nr. 3K-3432/2012).

Lietuvos Aukščiausiojo Teismo Civilinių bylų skyriaus teisèjų kolegijos $2012 \mathrm{~m}$. balandžio $12 \mathrm{~d}$. nutartis civilineje byloje Panevéžio miesto savivaldybès administracija prieš $A B$ „Panevéžio statybos trestas“ (bylos Nr. 3K-3-161/2012).

Lietuvos Aukščiausiojo Teismo Civilinių bylų skyriaus teisèjų kolegijos $2011 \mathrm{~m}$. gegužès $24 \mathrm{~d}$. nutartis civilinèje byloje $A B$ „Specialus autotransportas“ prieš Klaipedos miesto savivaldybès administracija (bylos Nr. 3K-3-249/ 2011).

Lietuvos Aukščiausiojo Teismo 2009 m. liepos 29 d. Viešųjų pirkimų reglamentavimo ir teismų praktikos apžvalga Nr. A-3, kat. 45.4. Teismu praktika. 2009, Nr. 31.

Lietuvos Respublikos civilinis kodekso komentaras. Šeštoji knyga. Prievoliu teise. Pirmas tomas. Vilnius: Justitia, 2003.

Lietuvos Respublikos viešųjų pirkimų įstatymas. Valstybès žinios. 1996, Nr. 842000; 2006, Nr. 4-102.

Lietuvos Respublikos civilinis kodeksas (su pakeitimais ir papildymais). Valstybès žinios. 2000, Nr. 74.

Lietuvos Respublikos viešųjų pirkimų įstatymo I-III skyrių komentaras [interaktyvus]. Vilnius: Advokatų kontora „LAWIN Lideika, Petrauskas, Valiūnas ir partneriai“, 2012 [žiūrèta 2013-09-01]. <http://www.ukmin.lt/ uploads/documents/Viesieji\%20pirkimai/121030_VPI_IIII_skyri\%C5\%B3_ komentaras_fn.pdf $>$.
Lietuvos Respublikos valstybès kontrolès išankstinio tyrimo ataskaita. Viešųjų pirkimų sistemos apžvalga, $2011 \mathrm{~m}$. lapkričio 25 d. IT-P-20-1-14, p. 36.

Lietuvos Respublikos viešųjų pirkimų istatymo $2,4,6,7,8^{2}, 9,10,13,18,22$, $24,28,33,35,39,40,56,85,86,87,90$ ir 92 straipsnių pakeitimo ir papildymo ịstatymo projekto aiškinamasis raštas [interaktyvus]. [žiūrèta 2013-09-01]. <http://www3.lrs.lt/pls/inter3/dok paieska.showdoc_l?p_id=447967\&p_tr $2=2>$.

Pasiūlymas Europos Parlamento ir Tarybos direktyva dèl viešųjų pirkimų* $\mathrm{KOM} / 2011 / 0896$ galutinis - 2011/0438 (COD) [interaktyvus]. [žiūrèta 201309-01]. </http://eurlex.europa.eu/Lex UriServ/LexUriServ.do?uri=COM:201 1:0896:FIN:LT:HTML>.

Perkančiųjų organizacijų prašymų dèl Viešųjų pirkimų tarnybos sutikimų pateikimo ir nagrinejimo ir pagrindimų Viešųjų pirkimų ịstatymo 56 straipsnio 5 dalyje nustatytais atvejais teikimo Viešųų pirkimų tarnybai taisyklès, patvirtintos VPT direktoriaus $2014 \mathrm{~m}$. spalio 6 d. įsakymu Nr. 2014-13796. Teisés aktu registras. 2014, Nr. 201413796.

Ribot, C.; Marc, E.; Idoux, P. Dico Moniteur des marchés publics: définitions, textes officiels, jurisprudences et avis. Le Moniteur Editions, 2008.

Tiekejjų kvalifikacijos vertinimo metodinès rekomendacijos, patvirtintos Viešųjų pirkimų tarnybos direktoriaus 2011 m. gruodžio 30 d. ịsakymu Nr. 1S196. Valstybès žinios. 2012, Nr. 5-163.

Transparency International Lietuvos skyrius (TILS). Lietuvos Respublikų ministerijų 2006-2010 metais vykdytų neskelbiamų viešųjų pirkimų analizè. [interaktyvus]. [žiūrèta 201309-10]. <http://transparency.lt/ media/ filer_public/2013/01/22/lr_ministeri- 
ju_2006-2010_metais_vykdytu_neskelbiamu_viesuju_pirkimu_analize.pdf $>$.

Tranparency International Lietuvos skyriaus pastabos dèl siūlomų Viešųjų pirkimų i̇statymo pataisų [interaktyvus]. [žiūrèta 2013-09-01]. <http://transparency.lt/media/filer_ public/2013/05/14/tils_lrs_del_viesuju_ pirkimu_istatymo_pakeitimo.p $>$.

Vilniaus apygardos administracinio teismo $2011 \mathrm{~m}$. gegužès $2 \mathrm{~d}$. nutartis administracinio teisès pažeidimo byloje Nr. II-380-171/2011.

Viešųjų pirkimų tarnyba. Viešujų pirkimu tendencijos gereja <http://www.vpt.lt/ rtmp8/dtd/index.php?nid=122146945 $6 \&$ module $=$ news \&lan $=$ LT $>$.

2004 m. kovo 31 d. Europos Parlamento ir Tarybos direktyva 2004/18/EB „Dèl Viešojo darbų, prekių ir paslaugų pirkimo sutarčių sudarymo tvarkos derinimo“ [interaktyvus]. [žiūrèta 2013-
09-01]. <http://www.vpt.lt/rtmp8/dtd/ index.php?pid $=121189211185 \&$ cid $=10$ 89791674\&sid=1\&lan=LT $>$.

$2004 \mathrm{~m}$. kovo $31 \mathrm{~d}$. Europos Parlamento ir Tarybos direktyva 2004/17/EB „Dèl subjektų, vykdančių veiklą vandens, energetikos, transporto ir pašto paslaugu sektoriuose, vykdomų pirkimų tvarkos derinimo" [interaktyvus]. [žiūrèta 201309-01]. <http://www.vpt.lt/rtmp8/dtd/ index.php?pid $=121189211185 \&$ cid $=10$ 89791674\&sid=1\&lan=LT $>$.

[interaktyvus]. [žiūrèta 2013-09-10]. <http://www.lrs.lt/pls/proj/dokpaieska.showdoc_l?p_id=8267\&p_query =vie $\%$ F0\%F8j\%F8\%20pir kim\%F8\%20 ex $\% 20$ ante \&p_tr $2=2 \& p \_f i x=n \& p$ gov $=\mathrm{n}>$.

[interaktyvus]. [žiūrèta 2013-09-01]. <http://eurlex.europa.eu/LexUriServ/ LexUriServ.do? uri=OJ:C:2013:086: 0011:0011:LT:PDF>.

\title{
FEATURES OF CHOOSING AND CONDUCTING NEGOTIATED PROCEDURE WITHOUT PUBLICATION OF A CONTRACT NOTICE, AS AN EXCEPTIONAL MEANS OF PROCUREMENT, BASED ON THE LAW OF PUBLIC PROCUREMENT ARTICLE 56 PART 1 PARAGRAPHS 2 AND 4
}

\author{
Eglè Sakalauskaitè \\ Mykolas Romeris University, Lithuania
}

Summary. The article analyzes the most problematic conditions of choosing negotiated procedure without publication of a contract notice and features of their execution. The focus is on the main conditions of negotiated procedure without publication of a contract notice, providing relevant court practice. It covers the following cases of choosing negotiated procedure without publication of a contract notice: when such manner of procurement is chosen due to emergency or unforeseen events; due to the fact that there were no suitable offers; also, to analyze the purpose of ex-ante publication, etc.

The main focus of the article is on the analysis of relevant problems in practice in choosing negotiated procedure without publication of a contract notice, in order to 
understand certain legal norms that regulate the choice of negotiated procedure without publication of a contract notice, as a manner of procurement.

The Law on Public Procurement contains very strict conditions for conducting negotiated procedure without publication of a contract notice. Due to specifity of conducting negotiated procedure without publication of a contract notice, it is important to assess the validity of choosing a procerement procedure in each individual case, and conduct the procedure very carefully by the following requirements of confidentiality, equality and transperancy, in order to prevent patronage cases of suppliers.

While conducting a procurement in accordance with the Law on Public Procurement Article 56 part 1 paragraph 4, it is very important that the urgency would be actually real and reasonable, caused by unforeseen event, and would be not declared, for example, as a misconduct of contracting authority in planning a need of procurement or inaction.

The article also analyzes the concept of "improper offer" and explains that the offer is considered to be inappropriate if it is irrelevant to the contract, because without substantive changes, it cannot meet the needs and requirements provided in procurement documents of the contracting authority ${ }^{63}$.

Keywords: procurement, negotiations, negotiated procedure without publication of a contract notice, report on a voluntary transparency of ex-ante.

Eglè Sakalauskaitė, Mykolo Romerio universiteto Teisès fakulteto Konstitucinès ir administracinès teisès instituto doktorantė. Mokslinių tyrimų kryptys: viešieji pirkimai, administracinè teisè.

Eglè Sakalauskaitè, Mykolas Romeris University, Faculty of Law, Institute of Constitutional and Administrative Law, doctoral student. Research interests: public procurement, administrative law.

63 Proposal for a Directive of the European Parliament and of the Council on public procurement /* COM/2011/0896 final - 2011/0438 (COD) [interactive]. [accessed on 2013-09-01]. </http:// eurlex.europa.eu/LexUriServ/LexUriServ.do?uri=COM:2011:0896:FIN:LT:HTML>. 